\title{
O homem viril desvelado: representações de masculinidade na arte funerária paulistana
}

\author{
The virile man: representations of masculinity in the \\ funerary art of São Paulo
}

\begin{abstract}
RESUMO
O artigo investiga representações de trabalho e masculinidade na arte funerária modernista da cidade de São Paulo, a partir de duas construções escultóricas integrantes do acervo do Cemitério da Consolação, pertencentes às Famílias Rizkallah Jorge e Calfat, de autoria de Antelo Del Debbio (1901-1971). Os túmulos são exemplos de propriedades de famílias imigrantes que se integraram à elite e fizeram uso da arte funerária como suporte de distinção social. Recorrem às representações de trabalho e masculinidade, sendo o labor o elemento que correlaciona os conjuntos funerários selecionados, observados por intermédio das lentes de Didi-Huberman. Analisa os lugares do trabalho, dos trabalhadores e dos imigrantes no cenário do período. Estes homens forjados em bronze simbolizam os sepultados e o lugar que os mesmos ocupavam enquanto vivos. Deste modo, ambas as esculturas, ancoradas nas trajetórias dos proprietários dos túmulos, configuram-se enquanto alicerce social: a força física é representativa da solidez social e econômica que seu trabalho ajudaria a compor.
\end{abstract}

Palavras-chave: Escultura funerária - Masculinidade - Nudez e seminudez Virilidade - Trabalho

\begin{abstract}
This article investigates representations of work and masculinity in the modernist funerary art of the city of São Paulo, from two sculpture sets in Consolação Cemetery, both authored by sculptor Antelo Del Debbio (1901-1971) and belonging to the Rizkallah Jorge and Calfat families. The tombs in question are examples of properties of immigrant families that integrated with the elites and made use of funerary art as a platform for social distinction. Both tombs make use of representations of work and masculinity in their sculpture settings, in such a way that labor is the key element that correlates the selected funerary buildings, observed through the lenses of Didi-Huberman. Their arrangements converted themselves in platforms of identity and analysis of workplaces of laborers and immigrants in São Paulo during that period. These men forged in bronze symbolize the buried and the place they occupied while they were alive. This way, both sculptures, anchored in the life stories of the tomb owners, shape themselves as social foundation: their physical strength is representative of the social and economic hardiness their work would help to compose.
\end{abstract}

Keywords: Funerary sculpture - Masculinity - Nudity and seminudity - Virility Work

* Pós-Doutoranda em História pelo Programa de Pós-Graduação em História, pela Universidade Federal de Mato Grosso (UFMT), Brasil. Doutora em História pela Universidade Federal de Goiás (UFG), Brasil. Autora de livros e materiais didáticos pelo IESDE - Inteligência Educacional e Sistemas de Ensino. CV: http://lattes.cnpq.br/8461204091007488 


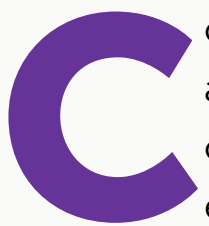

omo berço dos Jogos Olímpicos, a Grécia Antiga atribuía significativa importância ao esporte e ao cultivo do corpo. Homens concebiam o tempo nos ginásios como oportunidade de preparação para a guerra. Qualquer sinal de fraqueza ou debilidade era considerado como feminino e indesejável. O corpo deveria ser cuidado para garantir força e poder. Para Viegas (2008, p. 17), nessa sociedade de guerreiros a ênfase incidia sobre a integridade física; um corpo belo e forte era próprio dos homens ideais, dos aristoi - os melhores, na acepção grega antiga, àqueles indivíduos considerados "excelência pública". Esta cosmovisão certamente sugere a existência de determinados códigos de gênero, demonstrando que papéis masculinos e femininos são atribuídos social e culturalmente há muitos séculos.

A masculinidade não é aqui tratada enquanto discurso único, homogêneo e/ou verticalizado, mas como uma coleção de informações atribuídas e debatidas em diferentes tempos e espaços, assim como também ocorre com os discursos acerca da feminilidade. $O$ conceito de gênero tem sido uma categoria utilizada e difundida de forma crescente, sobretudo a partir da década de 1960. Matos (2005, p. 21-22) destaca que a proposta basicamente relacional deste conceito ressalta que "a construção do feminino e masculino define-se um em função do outro, uma vez que se constituíram social, cultural e historicamente em um tempo, espaço e cultura determinados."

Essa perspectiva remete às reflexões tecidas mais largamente por Scott em meados da década de 1980. Para a historiadora e feminista norte-americana, a categoria gênero deve abarcar não apenas as definições biológicas e/ou as relações de parentesco, mas também o mercado de trabalho e os sistemas educacional e político, esferas estas sexualmente segregadas e socialmente masculinas. Scott pontua que as relações entre os sexos são construídas socialmente e correspondem às mudanças nas representações de poder nos chamados "campos de força sociais". Em suas palavras: "(1) o gênero é um elemento constitutivo de relações sociais baseadas nas diferenças percebidas entre os sexos e (2) o gênero é uma forma primária de dar significado às relações de poder." (Scott, 1995, p. 86)

Diante do pressuposto de que as relações de gênero são um elemento constitutivo das relações sociais baseadas nas diferenças hierárquicas que distinguem os sexos, devem ser observadas como uma forma primária de relações significantes de poder, ainda segundo Matos e Scott, evitando-se as oposições binárias fixas e naturalizadas. No interior desse debate está inserida a reflexão sobre a categoria de masculinidade e seus códigos, associados às representações de trabalho, para os limites deste artigo, a partir de duas construções escultóricas integrantes do acervo do Cemitério da Consolação, em São Paulo, apresentadas e discutidas adiante. Conforme referido, tais códigos são forjados como parte da resposta ao problema da finitude na sociedade paulistana da primeira metade do século XX, nos quais a nudez/seminudez também desempenha relevante função. Na História da Arte, as representações da nudez corporal, sobretudo da masculina, provêm da antiguidade.

Era uma vez um nu, que conta a história de um corpo vestido em arte, the nude. O gênero do nu é considerado como forma ideal de arte [...], 
buscando sempre a mimeses do belo, como isso ele é um indicador da ideia dominante de arte e seu papel na sociedade [...], ou até os boundaries dela [...], porque é a representação do corpo possível de ser mostrada dentro da moral regente e de cada sociedade (Batista, 2010, p. 129).

Este diálogo entre a nudez e a arte remonta à arte grega clássica, quando o escultor, ao retratar o nu humano, buscava expressar a nudez do homem em si, colocava-se diante do próprio ser. Tal atitude se justifica porque, para o artista de então, o corpo humano não era um modelo, mas um módulo, representativo da harmonia absoluta. Tratar do nu na arte grega significa referirse à relação com o divino, porque o grego acreditava na existência do kosmos, em oposição ao kaos, de forma que a representação do corpo nu é equivalente ao próprio mundo ordenado (Andresen, 1992, p. 5-6). O desnudar expressa, além da beleza física, valorizada na antiguidade clássica, a virtude do cidadão, enquanto ser de harmonia e equilíbrio. A nudez masculina é parte primordial da escultura grega, representada nos Kouroi, estátuas masculinas inteiramente nuas. "Partindo de uma imagem que é o homem, o Kouros é um modelo para o homem" (Andresen, 1992, p. 27). Ao compor este modelo, esta imagem fundamental, o artista apresenta um projeto moralizador, de adequação do homem ao ideal democrático e cultural da civilidade grega.

Desse modo, a nudez corporal masculina comumente ocupou lugar de destaque, sendo temática relevante em diferentes momentos históricos e artísticos, desde a Antiguidade Clássica até a contemporaneidade, passando pelo Renascimento e o Neoclassicismo. Defende-se que um corpo nunca existe em si mesmo, nem quando está nu, conforme Katz (2008, p. 69). Corpo é sempre um estado provisório de uma coleção de informações que o constitui como corpo. Questionar o lugar da masculinidade e o significado da nudez, aqui associada às representações de labor, concerne à compreensão das concepções imaginárias do corpo pensadas enquanto narrativas, imbuídas de valores sociais e culturais. A nudez do masculino tem a função de construir determinado sentido, que pode ser interpretado à luz dos valores sociais, constituintes da corporeidade. Este viés rompe com uma leitura determinista e/ou biologizante: ser homem/ mulher vai além da existência de um corpo masculino/feminino. Segundo Nicholson:

Defendo que a população humana difere, dentro de si mesma, nao só em termos das expectativas sociais sobre como pensamos, sentimos e agimos; há também diferenças nos modos como entendemos o corpo. Consequentemente, precisamos entender as variações sociais na distinção masculino/feminino como relacionadas a [...] diferenças ligadas não só aos fenômenos limitados que muitas associamos ao "gênero" (isto é, a estereótipos culturais de personalidade e comportamento), mas também a formas culturalmente variadas de se entender o corpo (Nicholson, 2000, p. 14).

No entender da autora, o corpo deve ser pensando como uma variável e não uma constante. Deste modo, é possivel observar as atribuições de sentido dadas tanto aos corpos quando às ideias de feminilidade e de masculinidade que daí decorrem. Nesse sentido, Batista 
(2010, p. 125-126) pontua que o corpo na arte, tanto na literatura quanto nas artes visuais, é sempre um corpo-representação, um corpo imaginário que revela narrativas que objetivam conceder sentido aos corpos reais. As várias representações do corpo imaginário indicam negociações, no que diz respeito ao discurso do corpo, às relações e normas sociais, e aos valores de determinada sociedade. Deste modo, o corpo pode ser compreendido enquanto "materialidade polissêmica": "como união de elementos materiais e espirituais e também como síntese de sonhos, desejos e frustrações de sociedades inteiras, pois o múltiplo sentido do corpo pede múltiplos olhares" (Batista, 2010, p. 126). Essa polissemia do corpo é, portanto, uma polissemia da própria masculinidade.

A masculinidade, assim como a feminilidade, não é um caractere biológico. Trata-se do "fazer-se homem", ou seja, um processo individual/social que se realiza na cotidianidade espacial da construção de gênero como um elemento identitário primordial das relações humanas. A concepção dos elementos típicos e/ou necessários concernentes ao "ser homem" é construída e, ao mesmo tempo, relacional. Em conformidade com Silva et al (2011, p. 19), depreende-se que o gênero é uma representação, experienciada habitualmente, e não algo que se adquire. São as práticas de gênero que permitem, contraditoriamente, sua existência e transformação. Nesse sentido, não existe uma única forma de "fazer-se homem", mas múltiplas vivências possíveis, possiveis masculinidades que se forjam em diferentes tempos e espaços. Assim, apesar de considerar que a nossa sociedade está organizada a partir do privilégio do gênero masculino, não existe uma única forma de masculinidade.

Construída num contexto social, cultural e político, a masculinidade e suas formas de manifestação, no caso, relacionadas ao trabalho, devem ser compreendidas dentro dos suportes simbólicos de masculino e de feminino, próprios a cada sociedade. Vieira-Sena (2011, p. 38) esclarece que aquilo que se entende por tipicamente feminino e masculino não são imagens que correspondem a qualquer valor essencial, universal e atemporal, mas as imagens construídas historicamente e que, desde a modernidade, vêm sendo profundamente alteradas, graças à fluência e à confusão entre as fronteiras de gênero. Estas flutuações são contidas no fenômeno de fragmentação das identidades, aceleração, ritmo e do tempo, mudanças de papéis, entre outras transformações próprias da sociedade contemporânea.

Ainda que pareça haver uma única representação possível do masculino e do feminino, legitimada pelas relações de poder, o gênero enquanto categoria analítica "fornece um meio de decodificar o significado e de compreender as complexas conexões entre várias formas de interação humana" (Scott, 1995, p. 89). Todavia, essa significação não deve ser lida como algo inscrito de forma unilateral em um sexo previamente dado, entendido como um simples suporte, conforme pontua Butler (2013, p. 25). Gênero deve designar também, no entender dessa autora, o aparado de produção e estabelecimento dos próprios sexos - tão construídos e históricos quanto as relações de gênero e os conceitos de masculinidade e feminilidade. As esculturas ora em análise, coleções representacionais de masculinidade e trabalho, alimentadas pela conjuntura paulistana, decorrem dessas complexas relações de força e de poder, produtoras de sentido. 


\section{O trabalho como identidade do homem: suporte para a masculinidade}

Há milhares de anos, o trabalho é uma categoria identificadora do homem. Dentre as múltiplas teorias sobre a evolução humana e espécimes catalogados, destaca-se o chamado Homo Ergaster, popularmente denominado Homo Erectus Africano. Ergaster, vocábulo latino, significa "trabalhador". O mais provável ancestral humano conta com registros de labor: teria utilizado instrumentos de pedra, osso e madeira elaborados e tido bom domínio do fogo para o cozimento de alimentos e defesa, conforme resquícios fósseis de acampamentos desse hominídeo. Dawkins (2005, p. 66-67) sugere que esse espécime foi um dos primeiros a aventurarse territorialmente, propagando-se muito além da sua gênese africana.

Para atender as necessidades mais básicas para a própria sobrevivência, o homem foi imediata e irremediavelmente impulsionado ao trabalho, inicialmente com as próprias mãos e, progressivamente, com o auxílio de diferentes ferramentas, as quais foram sendo aperfeiçoadas a cada geração, evoluindo tanto quanto o próprio homem. Paulatinamente, o trabalho contribuiu para a construção de divisões no interior dos agrupamentos humanos, estabelecendo atribuições específicas, pautadas em diferenças de gênero, classes e/ou estamentos sociais, procedência e faixa etária. Ao mesmo tempo, ao trabalho foram sendo atribuídos distintos sentidos simbólicos.

Segundo Woleck (2002, p. 02), na Antiguidade, majoritariamente o trabalho era entendido como a atividade dos que haviam perdido a liberdade, cujo significado confundia-se com o de sofrimento ou infortúnio, com frequência vinculado à escravatura. A própria etimologia latina do vocábulo contém o sentido do trabalho enquanto atividade punitiva.

O significado de sofrimento e de punição perpassou pela história da civilização, diretamente se relacionando ao sentido do termo que deu origem à palavra trabalho. Essa vem do latim vulgar tripalium, embora seja, às vezes, associada a trabaculum. Tripalum era um instrumento feito de três paus aguçados, com ponta de ferro, no qual os antigos agricultores batiam os cereais para processá-los. Associa-se a palavra trabalho ao verbo tripaliare, igualmente do latim vulgar, que significava "torturar sobre o trepalium", mencionado como uma armação de três troncos (Woleck, 2002, p. 03).

Dentre os povos da Antiguidade, representações de trabalho e trabalhadores são habituais, sendo observadas especialmente em representações artísticas egípcias, gregas e romanas. É relevante observar que diferentes regimes de trabalho (escravo, servil, assalariado, autônomo, cooperativo, corporativo ou comunitário) incluem distintos códigos sociais e, por conseguinte, de masculinidade. Na tradição abraâmica, por exemplo, segundo Woleck (2002, p. 3), em conformidade com as narrativas do Antigo Testamento, o trabalho associava-se à noção de punição, de maldição, condenação pelo pecado original, assumindo a dimensão de obrigação, dever e responsabilidade: Tu comerás o pão e o suor do teu rosto $(G n 3,19)$. Por sua vez, o advento da cristandade contribui para a dignificação do conceito de trabalho, que passa 
a ser um instrumento para a conquista do Reino dos Céus e, por consequência, contribui para a manutenção da estrutura social própria do medievo.

Os escritos teológicos de Santo Agostinho (354-430) foram de fundamental importância para desfazer a concepção de trabalho como maldição. Para o filósofo da Igreja, ao estabelecer uma distinção entre o "exterior" e o "interior", o "visível" e o "secreto", o trabalho a rigor não é bom nem mau, porque é uma dimensão exterior. Portanto, será o uso que o ser humano, enquanto dimensão interior, fizer do trabalho que concederá sua valoração. Para Matias (2014, p. 258-265), o trabalho é a ferramenta para a transformação do mundo criado por Deus e, através de sua graça e do livre-arbítrio, o homem poderá escolher o caminho do bem e, assim, fazer da terra um melhor lugar para viver.

desde o século VIII, o termo labor e seus derivados e compostos [...] desenvolvem um novo sentido, centrado na ideia de aquisição, de ganho, de conquista, sobretudo no meio rural, onde a palavra se associa, de fato, à noção de arroteamento. Esta evolução semântica traduz outra conquista: a da promoção ideológica e mental do trabalho e dos trabalhadores. Valorização ainda ambigua, já que o trabalho é, sobretudo, exaltado para elevar o rendimento e a docilidade dos trabalhadores. Mas, tal valorização já é sem dúvida o resultado da pressão dos trabalhadores sobre a ideologia e a mentalidade medievais (Le Goff, 2013, p. 258).

Inicialmente punitivo, progressivamente tomado como inelutável ao longo do medievo, o trabalho passou a ser finalmente visto enquanto instrumento de salvação e como forma de realizar a vontade divina, com a ascensão da Reforma Protestante, a partir do século XVI. Para Barbosa (2007, p. 18), a Reforma Protestante ultrapassou o âmbito religioso e influenciou e/ou suscitou movimentos reformistas nas demais áreas da estrutura social, as quais também ultrapassaram as fronteiras nacionais - aí inclusa a esfera do trabalho. Nas palavras de Sanson:

A Reforma Protestante muda radicalmente a visão sobre o trabalho conduzindo-o a um pleno reconhecimento. Será através da Reforma, que o trabalho assumirá verdadeiramente um status de importância e contribuirá decisivamente para uma outra subjetividade manifesta no trabalho (2009, p. 28).

A partir da Reforma e subsequentes transformações, os séculos XVI e XVII assistiram à emergência de um novo sentimento individualista e racionalista, que consolida-se na emergência do lluminismo, no século XVIII - o chamado Século das Luzes. Da mesma forma, tais mudanças conjunturais também alimentaram a sedimentação do capitalismo na modernidade, da qual trata Weber, em A ética protestante e o "espírito" do capitalismo. Faz-se pertinente salientar que o protestantismo, em particular o Calvinismo, defende uma ética diferenciada, que se torna fundamental para a constituição de um novo olhar acerca do trabalho e do capital, em um viés cada vez mais individualizado. Diferente do que a Igreja havia postulado até então, o 
protestantismo não parece condenar o lucro, mas considera-o resultado de uma racionalidade metódica do próprio trabalho. Sanson (2009, p. 29-30) esclarece que é em Calvino que o trabalho assumirá um caráter mais radical de valorização, associado ao individualismo, passando a tornarse um dever - deve ser uma muralha contra a preguiça. Para além da dimensão religiosa, o protestantismo constrói os fundamentos para um novo ethos, no que se refere ao trabalho.

A visão protestante, para além de uma valorização religiosa do trabalho, contribui para criar um "espirito" motivacional para o empreendedorismo. A contribuição de Weber é mostrar que o capitalismo ensejado pela Revolução Industrial tinha, em sua base, uma concepção de trabalho vinculada ao ascetismo secular do protestantismo. Foi essa concepção de trabalho, que liberou moral e eticamente os homens - os capitalistas - à aquisição de bens, à obtenção do lucro, à cobrança de juros e à acumulação de capital. Esse ethos - conjunto de valores culturais - exortava que a acumulação do capital deveria ser reinvestida em novos empreendimentos que gerassem mais empregos. Esse círculo virtuoso - trabalhar, acumular e reinvestir - permitia o estabelecimento da harmonia social. Será esse ethos que fomentará a atividade capitalista (Sanson, 2009, p. 32).

No interior desse novo ethos, passa-se a valorizar a concepção do trabalho associada ao progresso humano, não apenas em termos econômicos. O progresso só é possível individualmente, mas é através do coletivo de individualidades que o todo acaba por progredir, mesmo no caso tecnológico. O trabalho passa a ser tomado sob um viés cada vez mais afirmativo, mais dignificante, que se pauta nos sentimentos de autonomia, individualidade e racionalidade humana. É esta dimensão que, com frequência, é expressa nas construções tumulares, nas quais o trabalho assume o papel de mitificador dos sepultados, pedra de toque da construção de suas identidades. Esse processo era parte de um movimento mais amplo de adequação (ou submissão) dos corpos aos "novos tempos", que se fazia presente também no contexto brasileiro.

Segundo Albuquerque Júnior (2013, p. 38), certas transformações na cultura de gênero foram motivadas pelo advento da República e a necessária ampliação do espaço social para a inclusão de novos grupos que emergiam com crescente influência e poder - comerciantes, industriais, operários e mulheres. No caso específico de São Paulo, a dinamização do processo de crescimento populacional e territorial da cidade intensificou-se a partir da virada do século e, com isso, novos códigos sociais emergiram. Para Matos:

Desde o inicio do novo regime, o programa politico republicano, sob a influencia da doutrina positivista, concentrou suas atenções no binômio família-cidade, base da proposta de estruturação do Estado, em que o conceito de pátria se baseava na família. Essa era vista, mais do que nunca, como o sustentáculo de um projeto normatizador, cujo desenvolvimento reequacionou seu papel e sua inserção social na cidade, já que a "nova família" fora estimulada a desenvolver práticas sociais que se adaptassem ao novo, ao moderno (Matos, 2001, p. 25). 
Paralelamente à intensa urbanização, ao final da escravidão, ao processo de imigração e à crescente industrialização, novos códigos de masculinidade e feminilidade se faziam necessários. Com a libertação dos escravos, separaram-se os homens de sua força de trabalho. Deste modo, segundo esclarece Chalhoub (2008, p. 65), as classes possuidoras não podiam garantir o suprimento da força de trabalho em seus empreendimentos por intermédio da aquisição de escravos. Isso impunha a necessidade de que os homens libertos se dispusessem a vender suas forças de trabalho para os empreendedores. Em outras palavras, os homens libertos deveriam se perceber enquanto trabalhadores.

Para isso, o trabalho deveria ser visto como uma atividade dignificante, conforme já pontuado. Especialmente no que dizia respeito aos homens, os novos códigos passaram a se centrar na importância do trabalho, buscando reforçar a identificação masculina com o mesmo, ao destacar seu papel de provedor. De acordo Matos (2001, p. 41-42), discursos políticos, religiosos e médicos reforçavam a necessidade do homem de ser resistente, jamais manifestando dependência ou sinais de fraqueza, devia ser "metódico, atento, racional e disciplinado". objetivo central era esse: cristalizar um ideal de masculinidade fundado na correspondência necessária entre homem e trabalho. Esta relação intrínseca se fazia ainda mais evidente ao se tratar do homem imigrante, em conformidade com a análise, mais adiante.

As classes dominantes esperavam que este fosse "morigerado, sóbrio e laborioso", cultivando as principais virtudes da ética capitalista: "o imigrante devia servir de exemplo ao trabalhador nacional" (Chalhoub, 2008, p. 77). Servia como um protótipo do homem e do trabalhador ideal, no contexto de industrialização que emergia na passagem do século XIX para o XX. É esta representação que seria transportada a tantas construções tumulares dos cemitérios paulistanos, especialmente àquelas pertencentes às famílias de imigrantes. A morte é uma problemática social, que se concretiza de múltiplas formas no espaço cemiterial em torno da busca por perenizar a memória do ambiente que o abriga. Portanto, o que se propõe ao longo deste artigo, com base nas duas composições tumulares selecionadas, é refletir sobre quais memórias são perenizadas por meio destas representações associadas ao labor.

\section{Cemitérios e arte funerária: uma dinâmica própria}

Oficialmente, os cemitérios públicos brasileiros foram secularizados ao final do século XIX, após a Proclamação da República. Ainda que o processo tenha sido encaminhado e pensado por membros da elite política e intelectual do período (Rodrigues, 2005, p. 298), gradativamente estes espaços funerários passaram a assumir novos papeis no espaço urbano. Ao serem novamente incorporados às cidades, após o transcurso do processo de medicalização e, em seguida, de secularização, os cemitérios passaram a refletir o universo de cada época e sociedade, nos quais cristalizam-se as relações entre as representações sociais, a memória e as práticas identitárias (Borges, 2002). Para Almeida: 
Dentre as várias leituras possiveis que podem ser realizadas acerca das cidades, uma delas diz respeito às suas características como lugares de memória e esquecimento. Compostas de fragmentos, vestígios do tempo que suscitam emoções. Estes sentimentos podem ser percebidos na medida em que esquadrinhamos os espaços nela constituídos. O cemitério é um desses lugares privilegiados nos quais afetos, lembranças e olvidamento se entrelaçam, possibilitando através de sua interpretação a escrita de uma história das sensibilidades. Os cemitérios tornam-se, pois, fontes incontornáveis nos quais se encontram os registros das impressões e experiências sensiveis formuladas pelos sujeitos em seu devir histórico (ALMEIDA, 2007, p. 319).

Portanto, a arte funerária não deve ser vista apenas como sinônimo de sacralidade - ainda que muitas vezes as necrópoles sejam tomadas pela via da religiosidade. Constitui-se com base em uma miríade de influências, advindas de tempos múltiplos, que em muito transcendem tanto a função primeira, o sepultamento dos corpos, quanto o âmbito religioso e/ou espiritual. Sobre a arquitetura e a estatuária funerária, Borges afirma:

Elas valem por si mesmas e sua presença é suficiente para integrar-se ao inconsciente coletivo da comunidade vigente. Como mantêm um compromisso com as representações do luto, alicerçadas no discurso religioso, moral e econômico do grupo social de que procedem, sua abrangência é mais ampla do que se supõe (Borges, 2003, p. 86).

No decorrer do século XIX, emergiu uma série de novos gestos referentes aos mortos, à morte e ao morrer, conforme pontua Sorio (2009, p. 26), organizados a partir de dois referenciais, quais sejam a família e a pátria, logo transportados aos cemitérios a céu aberto. As "novas" atitudes apresentavam-se em geral como reaproveitamento das tradições, eventualmente presentes há séculos, mas agora "deformadas e retomadas" sob novo ângulo. Os espaços da morte, sobretudo os cemitérios públicos, passaramom a conjugar elementos sacros e profanos, religiosos e civis, constituindo um universo familiar, um cenário cada vez mais propício para a exibição da chamada "morte burguesa".

Motta argumenta que, embora o "exercício genealógico" tenha sido comum entre as aristocracias, seria apenas a partir dos séculos XVII e XVIII que famílias burguesas demonstrariam interesse por compor representações de suas origens, manipulando-as, "com o intuito de criar novas identidades em razão do novo status socioeconômico adquirido" (2010, p. 61). Os túmulos dos antepassados passavam a ser um marco importante, nos quais gerações mais jovens podiam ter um referencial, vendo-se neles e projetando uma identidade familiar e um patrimônio simbolizado em pedra.

Assim, o gosto pelo túmulo de família passava a ser uma importante referência para as elites brasileiras urbanas, que logo se adaptaram aos novos padrões de uso e apropriação dos espaços cemiteriais públicos, 
bem como de suas lógicas de enterramento. Depois de alguns anos de inaugurados, os cemitérios passaram a concorrer entre si pela grandiosidade e luxo que suas construções tumulares eram capazes de exibir. [...] Anos mais tarde, seria a vez das novas fortunas, procedentes do capital financeiro especulativo, da indústria, de profissões liberais, assim como de outros setores das camadas urbanas que surgiam nas principais capitais do país (MOTTA, 2010, p. 61).

Assim, esta "morte burguesa" era uma forma de sedimentar em alvenaria a grandiosidade de um patrimônio material, primeiramente amealhado na forma de grandes propriedades e escravos e, posteriormente, de capitais reunidos a partir de atividades industriais e comerciais. Era também, por outro lado, uma forma de agregar gerações em torno de uma ideia de patrimônio construído, de riqueza erigida a partir de engenhosidade, diligência e esforço, uma imagem elevada de si, que se espalhava dos grandes nomes nas lápides para os seus descendentes. Borges salienta que a sociedade burguesa, como meio de afirmação social, passou a encomendar a escultores e artistas-artesãos obras que expressassem seu gosto e pequenas fantasias advindas do inconsciente coletivo, atitude sobre a qual estudiosos como Ariès (2003; 2014) e Vovelle (1997) também trataram:

\begin{abstract}
Adotando padrões estéticos convenientes a arte funerária contribuiu para desenvolver um ideário estético determinado. [...] essas construções tumulares estão imbuídas de signos que expressam valores religiosos e socioculturais de fácil assimilação. Enfim, a arte funerária burguesa misturou com harmonia os símbolos cristãos e profanos que despertam nos sobreviventes o mais profundo e significativo sentimento (Borges, 2004, p. 1).
\end{abstract}

Com o propósito de compreender as relações entre o nu e o seminu masculino, e as representações de masculinidades na composição da arte funerária burguesa, empreendi um inventário das ocorrências das esculturas funerárias despidas, parcial ou totalmente, constituídas no período Modernista, especialmente entre as décadas de 1920 e 1950, a partir do acervo artístico do Cemitério da Consolação. Escolhi este cemitério por ser um dos mais significativos espaços de sepultamento no Brasil, em virtude da própria conjuntura paulistana no período - que coincide com a expansão vultosa do tecido urbano de São Paulo.

Inaugurado em 1858, após uma série de debates médicos e políticos travados ao longo da primeira metade do século $\mathrm{XIX}_{1}^{1}$ paralelamente à redefinição da concepções de salubridade e de morte na capital paulista, o Cemitério da Consolação foi se constituindo paulatinamente como um suporte para a demonstração da afluência material das famílias burguesas. Para Valladares (1972, p. 1075), esta necrópole é a que melhor representa a fortuna pauliceia, em função da presença dos túmulos de propriedade dos cafeicultores e posteriormente dos industriais. Neste espaço,

\footnotetext{
1 Sobre a criação dos cemitérios extramuros em São Paulo, consultar: Camargo, 2007; Cymbalista, 2002; Matrangolo, 2013; Pagoto, 2004 e Rezende, 2006.
} 
observa-se o uso inicial da nobre estatuária de mármore importada e em seguida dos túmulos de blocos de granito com estatuária de bronze, constituindo um "depósito de todos os estilos e gostos" (Valladares, 1972, p. 1087).

O Cemitério da Consolação conta ainda hoje com uma grande quantidade de túmulos pertencentes à personagens da chamada "velha cultura do café", expressão esta utilizada por Martins (2008a, p. 12). Segundo o autor, ali se encontram sepultados vários indivíduos que foram responsáveis pela transição do trabalho escravo para o trabalho livre, como Antônio da Silva Prado (1840-1929), bem como grandes empresários, principalmente industriais, que disseminaram a moderna economia capitalista em São Paulo e no Brasil, como Diogo Antônio de Barros (1791-1876) e Roberto Cochrane Simonsen (1889-1948). À medida que ia sendo absorvida ao perímetro urbano paulistano, segundo Rezende (2006, p. 99), foi se tornando uma necrópole para os ricos, em função das concessões perpétuas. Além disso, a área de seu entorno também foi progressivamente valorizada ao longo do século XX, inclusive em termos imobiliários e ambientais, sendo atualmente considerada uma região nobre da capital paulista.

Do acervo da arte funerária do cemitério em questão, uma das escolhas burguesas mais numerosas é a imagética relacionada ao trabalho. Desta, um dos artistas mais profícuos foi o escultor italiano Antelo Del Debbio (1901-1971). ${ }^{2}$ Ao estudar os escultores italianos e sua contribuição à arte tumular paulistana, Ribeiro (1999, p. 252-254) identificou mais de oitenta obras funerárias advindas do ateliê de Del Debbio, que funcionou em plena atividade até a década de 1960. Segundo a autora, o artista teve uma clientela diversificada, construindo desde jazigos simples, seguindo um projeto padronizado, com apenas vasos ou portões simples, por exemplo, até obras monumentais exclusivas, de significativo valor estético e artístico.

Ruggiero (2014, p. 89) salienta que Del Debbio se tornou um dos escultores mais afirmados na grande cidade brasileira, São Paulo, sendo de sua autoria uma grande quantidade de monumentos funerários contratados pelas famílias da alta burguesia da pauliceia. Sua temática é essencialmente religiosa, com muitas ocorrências de Maria e de Cristo, embora seja possível encontrar obras alegóricas e composições celebrativas de personagens ou famílias emergentes, sobretudo de origem sírio-libanesa - que é o caso de ambas as obras escolhidas para a análise neste artigo. Os túmulos em questão, pertencentes às Famílias Rizkallah Jorge e Calfat, particularmente, são exemplos de propriedades de famílias imigrantes que, ao se instalarem em São Paulo, integraram-se à elite e utilizaram a arte funerária como suporte de distinção social.

A temática escolhida por ambas as famílias relaciona-se ao trabalho, o que oferece subsídios para refletir sobre a caracterização da arte funerária no período em questão, quando os códigos de gênero e, mais especificamente, novas representações de masculinidade estavam se afirmando, conforme pontuei anteriormente. Enquanto à mulher cabia o papel de mãe e esposa, ao homem era reservada a função de provedor. "O homem teria sua função social de provedor viabilizada pelo trabalho, fonte básica de auto realização, veículo de crescimento

2 O artista nasceu em Viareggio, na Itália, radicou-se no Brasil em 1904. Após ter sido discente do Instituto de Belas Artes de São Paulo, retornou à Itália para estudar na Scuola Dell'Arte Della Medaglia, em Roma e em Lucca. No Brasil, venceu concursos para a construção de diversas obras escultóricas, entre as quais os monumentos à Revolução de 1932, em Santos e em São Carlos, e o Monumento a Camões, oferecido pela colônia portuguesa de Ribeirão Preto. 
pessoal, sendo através do trabalho reconhecido como homem. Sem o trabalho o homem não poderia ser considerado como tal" (Matos, 2005, p. 42). O trabalho era visto como padrão de masculinidade, como identificação máxima do homem - motivo da escolha deste motivo para as construções tumulares selecionadas.

Para a escolha, realizei diversas visitas exploratórias ao Cemitério da Consolação, observando a distribuição espacial dos túmulos, sua temporalidade e caracterização geral, para apreender a maneira como se inserem na malha urbana paulistana. A partir do pressuposto de que o sentido da nudez está para além do despir de um corpo, considerei que esta desempenhava uma função discursiva naquele espaço e conjuntura. Como as representações associadas às práticas de trabalho eram mais numerosas, sobretudo dos túmulos de famílias imigrantes, revelaram-se certas similitudes e disparidades sobre o emprego da nudez na arte funerária ${ }^{3}$, e propiciaram a escolha das duas construções funerárias em análise, por serem de autoria de Del Debbio, apresentarem uma associação entre masculinidade e trabalho e serem de famílias imigrantes.

Para a operacionalização da investigação destas representações do nu e do seminu e das masculinidades, foi necessário examinar as características do masculino (Gutmann, 1997, p. 387). Faz-se pertinente salientar que a inscrição dos sujeitos obedece à ordem simbólica - os corpos masculinos e/ou femininos podem se inscrever em lugares diferenciados, até mesmo contraditórios. Deste modo, observo que a análise da masculinidade deve contemplar às diferentes maneiras de ser homem, ou diferentes masculinidades, "ampliando as possibilidades de compreender os processos de atribuição de gênero" (Piscitelli, 2004, p. 185), o que permite observar mais atentamente como as características vistas como masculinas são utilizadas e relacionadas, para compor as esculturas selecionadas.

Diante disso, observou-se a morfologia das imagens, atentando primeiramente para a representação das diversas características físicas (compleição, pelos faciais e corporais, cabelos, faixa etária), em segundo lugar para a pose e gestos corporais marcantes na composição destas figuras e, finalmente, de possíveis figurinos, panejamentos e atributos adicionais na mise-enscène. ${ }^{4} \mathrm{O}$ discurso de masculinidade em cada escultura é obtido a partir da representação conjunta do físico, do posicionamento do(s) personagem(ns) e dos elementos aditivos. Em conformidade com o que Gutmann (1997, p. 386) defende, masculinidade é uma performance.

\footnotetext{
3 A partir do inventário das ocorrências de imagens masculinas, parcial ou completamente despidas, observou-se que estas se utilizam de representações que ora destacam a sensibilidade perante a morte, ora deixam em relevo a virilidade em associação ao mundo do trabalho; opções nem sempre em consonância com a moral burguesa e o ideal de masculinidade do período.

4 Cada um dos túmulos, enquanto conjugação do suporte arquitetônico e das composições escultóricas, é entendido como uma mise-en-scène, uma composição específica e organizada dos elementos cênicos. Por significar literalmente "colocar em cena", o termo compreende, na linguagem teatral e cinematográfica, a organização dos componentes em cena: cenário/espacialidade, iluminação, caracterização/figurino e atuação (Bordwell \& Thompson, 2001, p. 90). A partir dessa prática, o diretor determina o que é incluído ou não em cena, criando uma visualidade narrativa fechada. Embora o elemento da iluminação artificial não se faça presente na composição de um conjunto estatuário como os analisados neste trabalho, estes incorporam, tal qual uma peça ou um enquadramento fílmico, uma organização espacial determinada, e os personagens são apresentados com uma caracterização específica e gestual que contribuem para a fruição figurativa e simbólica das figuras. A devida análise da estrutura de cada um dos túmulos selecionados implica, portanto, a leitura da respectiva mise-en-scène, que inclui uma espacialidade determinada, a disposição dos personagens e sua caracterização, além dos gestos e poses.
} 
De forma ampla, a metodologia empregada considerou, em um primeiro momento, os elementos da forma, amparada pelas reflexões acerca da escultura enquanto linguagem artística, de seu suporte (neste caso, o espaço funerário), com suas funções próprias, e as determinações do contexto paulistano da primeira metade do século XX - sobretudo no que diz respeito à expansão urbana e suas consequências. Mas, para além da forma, observa-se a temática emergente das obras, sob o viés da História da Arte e das lentes de Didi-Huberman, e a maneira como cada imagem apresenta um "tempo ferido", para se posicionar diante da finitude.

A primeira obra didi-hubermaniana a ser traduzida para o português e publicada no Brasil foi O que vemos, o que nos olha (1998). A expressão que dá título à obra e que apresentou Didi-Huberman ao público brasileiro foi emprestada de Ulysses, de James Joyce (2012), e desde então tem sido amplamente utilizada nos círculos de estudo imagético. Faz referência às tensões entre observador e coisa observada - mais que uma relação unilateral, aquilo que observamos, também nos observa. Em suas palavras: "Ora, imagem não é horizonte. A imagem nos oferece algo próximo a lampejos (lucciole), o horizonte nos promete a grande e longínqua luz (luce)." (Didi-Huberman, 2011B, p. 85)

Em se tratando do universo da arte, o aprendizado é interminável, visto ser um campo instigante em si mesmo, com leis e aventuras próprias. Uma imagem não é o simples resultado de uma transposição do real, mas é o produto do processo de leitura realizado pelo artista, a ser também apreendido pelo observador. "Talvez o mais importante seja que, para apreciarmos tais obras, há que ter um espírito leve, pronto a captar as sugestões mais sutis e a responder a cada harmonia oculta", defende Gombrich (2013, p. 33).

Nesta perspectiva, refletir sobre as obras funerárias na perspectiva da história da arte, segundo Didi-Huberman, significa tomá-las enquanto "objectos problemáticos para a historicidade em geral, objectos para abrir a história até o cerne dos seus modelos de inteligibilidade bem como dos seus instrumentos de interpretação." (2011a, p. 11 - grifado no original) Para o autor, abrir não significa somente ampliar, mas também ferir: é um ato de perfurar a imagem para se colocar diante do tempo. Mais do que uma ampliação do olhar acerca das imagens, proposto aqui, portanto, trata-se de uma abertura que atravesse os territórios da arte e da história, para que as imagens sejam capturadas e englobadas na ordem temporal/espacial que as precede. Em suas palavras:

Ampliar o seu domínio às imagens é adoptar, certamente, novos objectos, mas é também capturá-las, englobá-las na ordem que as precede. É olhar a interdisciplinaridade pelo mero prisma das relações territoriais, de modo que "ampliar-se" às imagens corresponda, mais ou menos, a estender o seu império e a sua autoridade a novas paisagens e a novos objectos. Muito diferente é a abertura que fere, perfura ou atravessa o território que acolhe a operação. Com efeito, só essa possui uma dimensão crítica, uma capacidade extraterritorial de atravessar as fronteiras, de criar caminhos inéditos e de modificar a consistência - começando pelos usos e costumes, as retóricas da autoridade - do território atravessado (DidiHuberman, 2011a, p. 11) 
Tomar a história da arte sob esse prisma diz respeito a assumir um posicionamento crítico, que permita que os vocábulos em questão - Arte e História - possam se criticar e transformar reciprocamente. Trata-se de abrir as fronteiras disciplinares, conceituais e linguísticas, permitindo que os domínios do historiador sejam modificados pelas clivagens da arte, mesmo no seio dos seus modelos teóricos melhor estabelecidos, ainda conforme DidiHuberman. Propõe-se, como chave de leitura de imagens funerárias a partir deste autor, "ferir" tanto o território histórico quanto o cemiterial, na medida em que se compreendem as imagens como dispositivos capazes de posicionar o humano sempre diante do tempo.

Didi-Huberman defende que as imagens tocam o real - até porque seria um enorme equívoco crer que a imaginação é uma simples faculdade de desrealização. Em sua opinião, uma das grandes forças da imagem é criar ao mesmo tempo sintoma (interrupção no saber) e conhecimento (interrupção no caos), porque imagem é "uma impressão, um rastro, um traço visual do tempo que quis tocar, mas também de outros tempos suplementares - fatalmente anacrônicos, heterogêneos entre eles" (2012, p. 216). As imagens expressam o poder e a força do pensamento figurativo e, uma composição funerária, seja sacra, seja profana, é representativa das esferas relacionais que alimentam seus sentidos e intenções significantes. Para Didi-Huberman (2012, p. 222), é preciso saber ver nas imagens aquilo de que elas são as sobreviventes. Assim a história, liberta do puro passado (enquanto absoluto e/ou abstração), pode contribuir para abrir o presente do tempo. Nesta abertura, abre-se a possibilidade de observar a masculinidade como performance e a maneira como os códigos de gênero são construídos no espaço funerário, para a perenização da trajetória dos sepultados.

\section{Atributos de trabalho: a morte e a identidade do imigrante burguês}

A primeira escultura a ser analisada procede do túmulo da Família Rizkallah Jorge (1949), situado no Cemitério da Consolação, de autoria do escultor Antelo Del Debbio (1901-1971) (FIGURA 01). 
FIGURA 01 - Túmulo da Família Rizkallah Jorge (1949), relevos em bronze de Antelo Del Debbio, Cemitério da Consolação.

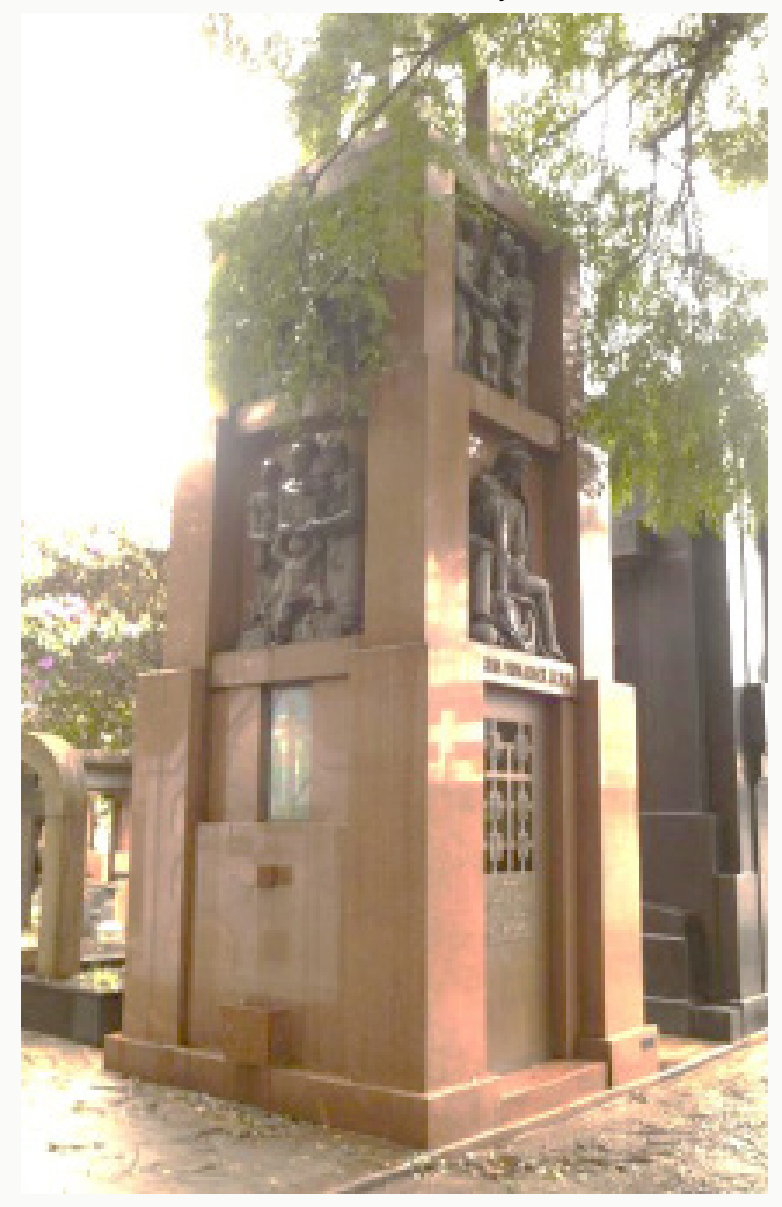

FONTE: Acervo da autora, 2014.

Trata-se de uma edificação em formato capelar, com dimensão monumental e verticalizada, predominantemente construída com uso de linhas retas, revestida por placas de granito polido marrom.

O projeto arquitetônico é verticalizado e consiste na superposição de três volumes de granito, todos com base quadrada, mas progressivamente menores, no sentido ascendente. O bloco inferior é ligeiramente mais elevado que os demais. No alto, o conjunto é arrematado por um campanário de granito com um sino de bronze.[...]

O acesso à capela se faz por uma alta porta frontal de bronze, cuja metade superior apresenta um fundo de vidro, entrecruzado por duas lâminas verticais de bronze e três horizontais. Sobre cada uma das seis intersecções dessas barras, vê-se um pequeno painel retangular - igualmente em bronze - com símbolos alusivos à Paixão de Cristo, a saber: tenaz e colher de pedreiro; três lanças; três cruzes; as iniciais JHS e uma cruz; os cravos da crucificação; um azorrague. Uma cruz de bronze sobrepõese ao conjunto, exceto no quinto superior da parte envidraçada. Abaixo desta, veem-se diversas inscrições em árabe (Ribeiro, 1999, p. 400-401). 
Em cada face da construção foram inseridos dois conjuntos escultóricos confeccionados em bronze, todos com as mesmas dimensões. Nas faces frontal e posterior da edificação encontram-se figurações que remetem primordialmente à família (FIGURA 02).

FIGURA 02 - Detalhes dos relevos frontais e posteriores do Túmulo da Família Rizkallah Jorge

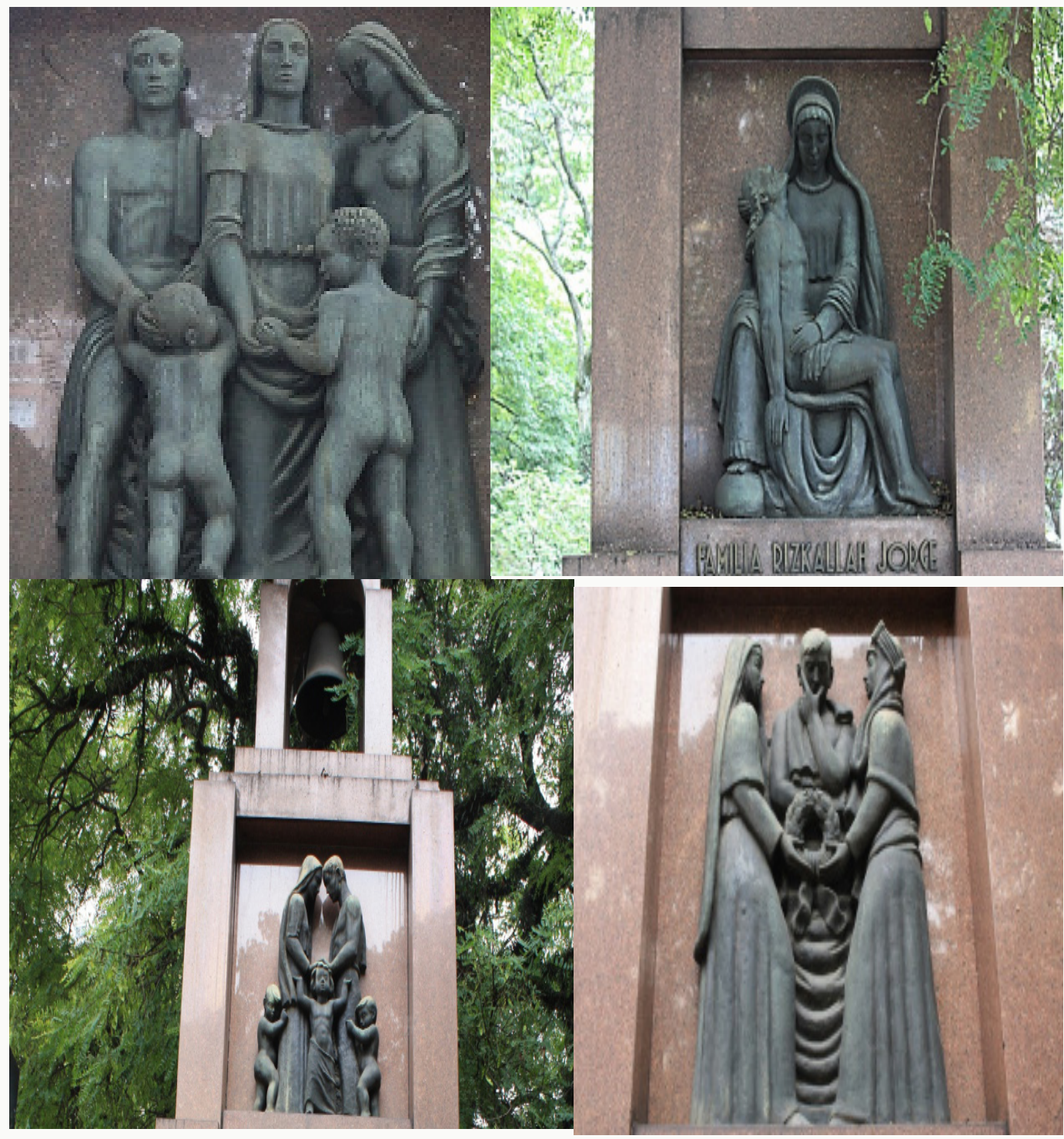

FONTE: acervo da autora, 2014.

No primeiro nicho, um trabalhador de corpo nu, acompanhado por duas mulheres e duas crianças. A figuração inferior é de uma Pietà, com os traços escultóricos próprios do artista - dramaticidade contida e pose hierática. Na parte posterior, encontra-se no painel superior outra composição que faz referência ao conceito de família: um casal acompanhado por três crianças. Enquanto a mulher apresenta uma vestimenta peculiar às representações bíblicas femininas, o homem tem o torso nu e calças contemporâneas - vestuário comum, no período, para um homem de classe operária. No painel inferior, a figura do mesmo trabalhador em 
segundo plano, é acompanhada por outras duas imagens femininas. Uma traja vestuário árabe, possivelmente uma referência à origem do sepultado, e a outra é figurada a partir de convenções bíblicas; ambas portam uma guirlanda, representativa da saudade, diante da finitude.

A imagem composta por Del Debbio (FIGURA 03) é alusiva ao trabalho, eixo a partir do qual se constrói a concepção de masculinidade.

FIGURA 03 - Detalhes dos relevos laterais do Túmulo da Família Rizkallah Jorge.
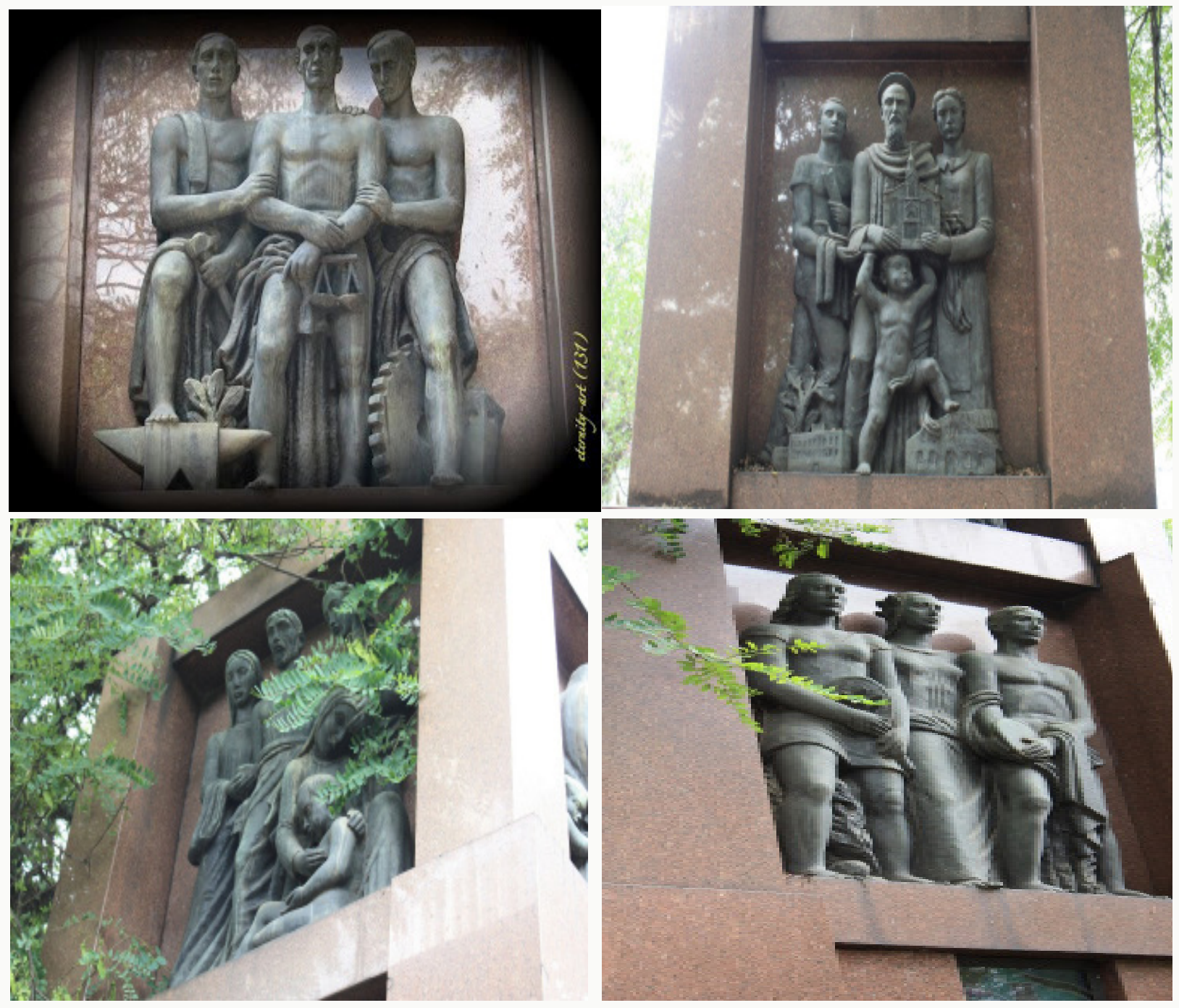

FONTE: acervo da autora, 2014.

Aos pés das três figuras masculinas desnudas há uma bigorna e uma roda dentada. Segundo Chevalier e Gheerbrant (2006, p. 783), a roda participa da perfeição sugerida pelo círculo, com certa valência de imperfeição: refere-se ao mundo do vir a ser, da contingência, da criação contínua. É a associação com a criatividade que incentiva o uso como referencial de trabalho. A figura central porta uma balança alusiva tanto à justiça quanto à prática do comércio - elemento fundamental na biografia do sepultado. O painel abaixo evoca as atividades filantrópicas da Família Rizkallah Jorge, que incluem o Orfanato Lar Sírio e a Igreja São Jorge, ambos os edifícios representados em 
forma de maquetes, acompanhando as figuras em questão: um santo, uma mulher, um jovem e uma criança.Na lateral direita, no nicho superior, o trabalhador é representado juntamente com três figuras femininas, uma das quais ampara uma criança, exaltando o conceito de amor materno. Uma vez mais Del Debbio recorre à edificação dos valores burgueses, sendo um deles o da instituição familiar, entrevisto pela figuração da mãe, recorrente nos diversos painéis. Por sua vez, no oitavo e último nicho há três figuras, alusivas ao esporte: uma mulher segurando uma raquete e uma peteca, uma segunda mulher com uma coroa de louros, e um homem com um disco. A imagem masculina, em especial, está nua, coberta apenas por uma faixa de tecido, exibindo uma musculatura vigorosa, que sinaliza a virilidade e a constituição do ser homem, tal como os homens trabalhadores do primeiro painel lateral, à direita.

Os personagens compostos por Del Debbio possuem uma pose hierática, sóbria e contida. Não apresentam gestos bruscos ou dramaticidade. Há que se salientar: o trabalhador ideal é sóbrio, porque acreditava-se que um indivíduo ocioso não possui educação moral, responsabilidade ou respeito pela propriedade (Chalhoub, 2008, p. 74-75). O geometrismo da capela, inspirado pelo art deco, também se encontra presente na concepção das figuras. $O$ tratamento anatômico é volumétrico e moderno, como ocorria com as obras de Arturo Martini $(1889-1947)^{5}$. A monumentalidade da construção vertical engrandece os sepultados, ao mesmo tempo em que o conjunto de painéis objetiva a construção de uma narratividade identitária para eles. Entretanto, a compreensão do enredo proposto por Del Debbio é prejudicada pela abundância e concentração de personagens e atributos.

No todo, a configuração escultórica de Del Debbio é alusiva à família, ao trabalho e aos valores considerados relevantes pela Família Rizkallah Jorge, como as atividades filantrópicas do sepultado. O imigrante armênio Rizkallah Jorge Tahan (1867-1949), ao desembarcar no porto de Santos, passou a se dedicar à fundição de cobre. Após três anos inaugurou a chamada Casa da Bóia. A empresa do imigrante, inicialmente dedicada à confecção de boias sanitárias, continua em atividade, atuando como distribuidora de metais não ferrosos e materiais hidráulicos. Nas palavras de Geraissati:

Sua trajetória na capital foi bastante singular. Ao contrário da maioria dos imigrantes de mesma procedência que chegavam à cidade e se envolviam com a comercialização de tecidos e outros objetos, tornando-se, assim, mascates, Rizkallah Jorge procurou uma profissão que se adequasse à atividade que exercia em sua terra natal: a fundição de cobre. Isto mostra uma peculiaridade deste imigrante dentro do grupo de sírio-libaneses que imigraram ao Brasil, pois a grande maioria destes homens eram camponeses analfabetos, já este sabia ler, escrever e era um artesão bem posto em sua sociedade de origem, algo que era notado dentro da comunidade aqui fixada e que foi explorado por ele como fator de distinção social e de capitalização (Geraissati, 2013, p. 340-341).

5 A obra de Del Debbio parece dialogar estreitamente com a fórmula da arte monumental italiana, própria sobretudo da primeira metade do século XX, quando convergiram tendências modernistas, como o Futurismo, e academicistas, como o retorno à ordem. Isso resultou em um equilíbrio delicado, sintetizado no trabalho de artistas como o italiano Arturo Martini (1889-1947). 
A edificação projetada pelo imigrante é um dos principais exemplares do ecletismo arquitetônico na capital paulista, tendo sido tombado pelo Conselho Municipal de Preservação do Patrimônio Histórico, Cultural e Ambiental da Cidade de São Paulo em 1992 e restaurado em 2008 (FIGURA 04).

FIGURA 04 - Fachada da Casa da Boia (início do séc. XX), fotografia de autoria desconhecida, Museu da Casa da Boia.

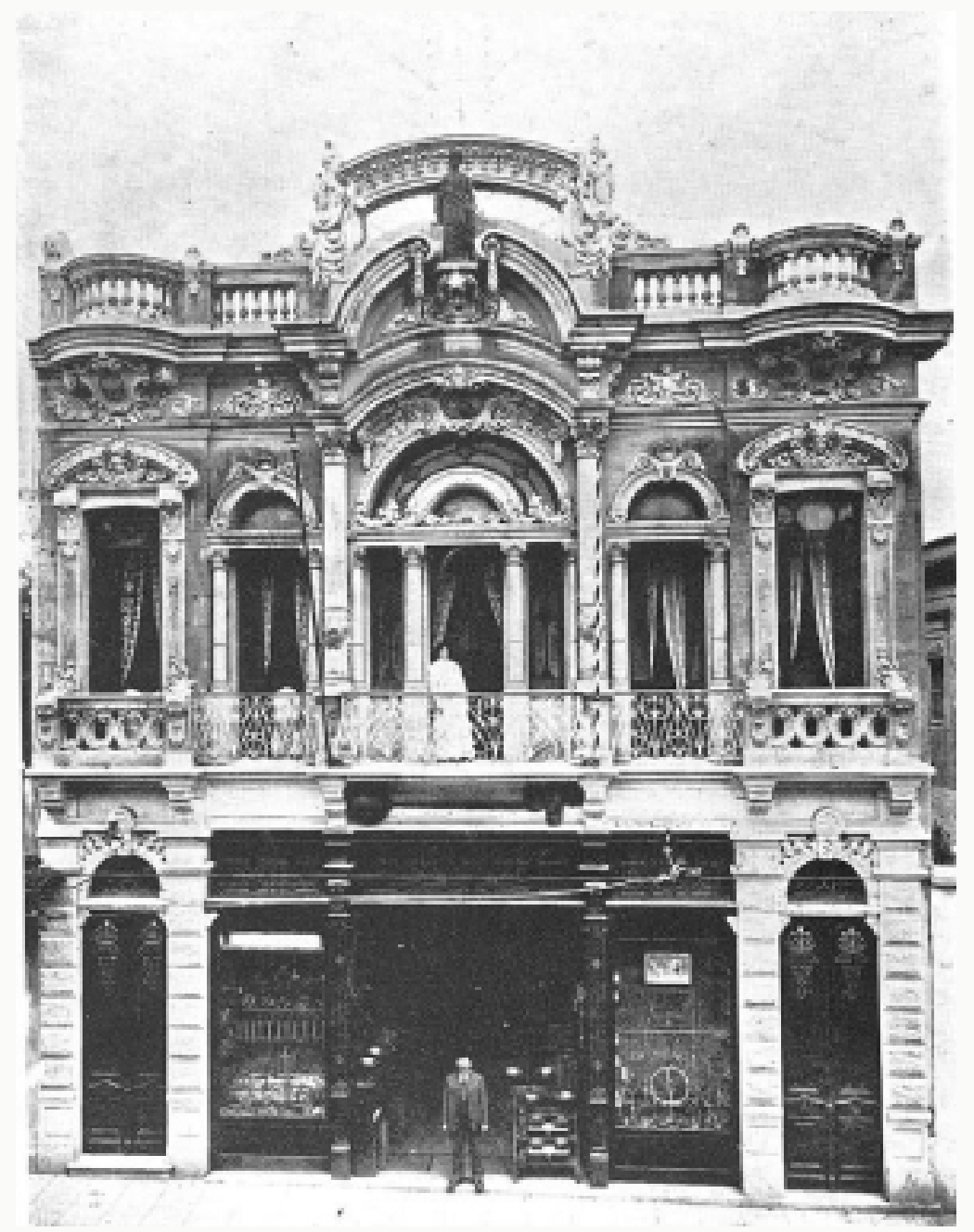

FONTE: acervo da autora, 2014.

Originalmente, o andar térreo possuía funções comerciais e o pavimento superior servia de moradia ao proprietário e seus familiares. Atualmente o prédio abriga a empresa da família - a Casa da Boia, e um museu, que busca preservar a historicidade de seu empreendedor, Rizkallah Jorge. Segundo Geraissati (2013, p. 347), a filantropia foi o principal fator que contribuiu para afirmar o imigrante nas comunidades que frequentou, e para sua mitificação. A leitura conjunta 
dos elementos tumulares concebidos por Del Debbio e da trajetória do sepultado Rizkallah Jorge evidencia o lugar concedido ao trabalho, numa perspectiva dignificadora do ser homem. Este é a espinha dorsal da figuração do escultor, que contribui para a mitificação do imigrante, enquanto burguês que conquistou um lugar de destaque na tessitura industrial de São Paulo. Seu desempenho de sucesso é marcadamente exaltado, mediante os conjuntos escultóricos, que também fazem constante referência à família e ao lugar ocupado pelo sepultado em seu meio social: mais do que um imigrante ou um burguês bem-sucedido, ressalta-se o trabalhador. Este é o discurso de masculinidade tecido por Del Debbio. Nas palavras de Piscitelli:

\begin{abstract}
Nos relatos, antigos e recentes, o denominador comum no qual se assentam as considerações sobre as diversas maneiras de ser homem é o trabalho. Concebido como instrumento através do qual se concretizam as possibilidades "criadoras" e transformadoas (da matéria, "da terra e dos homens") e como arma indispensável na luta, o trabalho, apresentado como constituinte da masculinidade, converte-se no eixo em torno do qual são tecidos [...] os estilos de ser homem (Piscitelli, 2004, p. 193).
\end{abstract}

As representações do trabalho, discursivas sobre a masculinidade, não se restringem à arte funerária. Durante o período realista, destacam-se as obras de Gustave Courbet (1819-1877), artista preocupado em representar o cotidiano e os trabalhadores, como vê-se em Os quebradores de pedra $(1849)^{6}$ (FIGURA 05).

No centro da composição estão dois trabalhadores, um adulto, que reduz pedras com um martelo, e um menino, que carrega os fragmentos em um grande cesto, possivelmente filho do primeiro. Ambos são representados de forma pouco idealizada, debruçados sobre suas tarefas com resignação. Seus rostos não aparecem, de modo que seus trajes, gastos e rasgados, compõem sua identificação: são anônimos, como tantos outros trabalhadores; o próprio cenário parece indicar que vivem à margem. Junto dos trajes, as ferramentas e a marmita postas de lado, em meio ao local de trabalho, compõem um cenário de simplicidade e rudeza. Ao fundo, destaca-se a grande sombra de uma colina, que dá espaço a um pequeno fragmento de céu. Os trabalhadores, em sua movimentação forçosa e monótona, destacam-se contra o painel desolado e monocromático.

6 Exposta em Dresden, infelizmente foi destruída no bombardeio da cidade em fevereiro de 1945, durante a Segunda Guerra Mundial. Os quebradores de pedra, obra considerada por muitos como fundadora do realismo, despertou inúmeros comentários críticos, à época de sua concepção. Exposta no Salão de Paris em 1850-1851 juntamente com Os camponeses de Flagey retornando da feira (1848) e Enterro em Ornans (1850), constitui com estes uma espécie de trilogia realista de Courbet (Taylor, 2005, p. 552-554). 
FIGURA 05 - Os quebradores de pedra (1849), óleo sobre tela de Gustave Courbet, destruída.

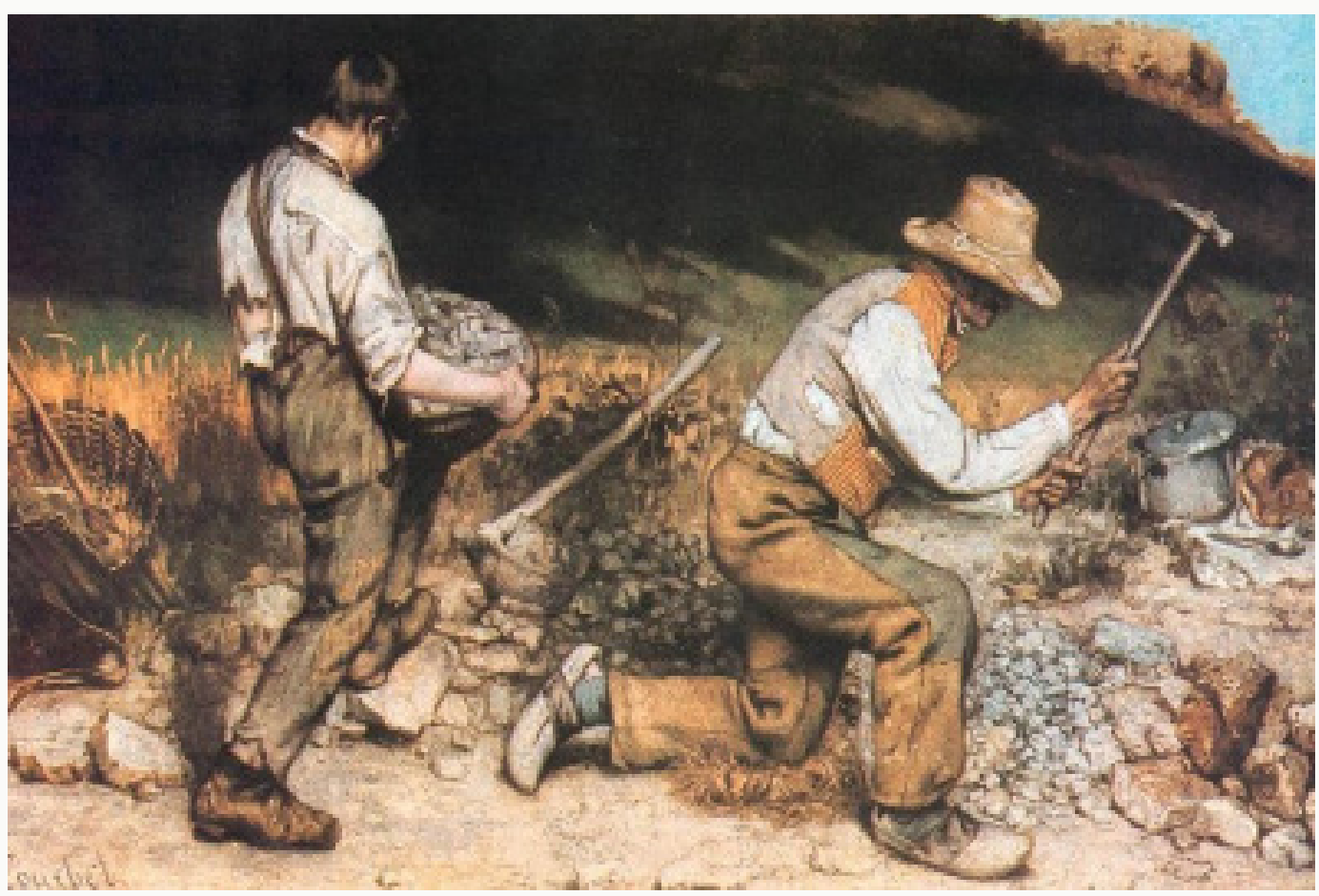

FONTE: FABRIS, 2013, p. 171.

Portanto, representados de maneira quase fotográfica, os dois quebradores de pedra de Courbet são figurados em trajes humildes em uma paisagem ruralista. O artista é considerado o criador do realismo social na pintura, ao voltar-se para temas cotidianos e à figuração de personagens ordinários, como os ferreiros de Goya.

Courbet voltou-se à pintura de pessoas comuns, trabalhadores, camponeses, burgueses rurais. Mas estes às vezes recebiam o escopo monumental que deveria ser reservado à pintura histórica. O realismo significou o "desaparecimento do tema", no sentido de uma cena ou evento já tornado canônico pela história, pela religião ou pela cultura clássica e que a pintura se propõe a representar. Mas os acontecimentos comuns sem esse significado estabelecido recebem a dignidade de tratamento antes restrita aos que o possuíam. Isso foi intencionalmente uma rejeição da hierarquia e, em certo sentido, um deslocamento. Esses novos "temas" estavam tomando o lugar dos antigos; uma afirmação estava sendo feita sobre sua dignidade (Taylor, 2005, p. 554).

Courbet não pretendeu idealizar suas representações do cotidiano. Suas obras buscam propriamente a expressão do real, renunciando em especial a toda retórica romântica, que lhe 
era contemporânea. A dignificação do trabalhador não se dá pela via da idealização do tema, mas pela visualidade que concede a personagens comuns, anônimos - como os quebradores de pedra. Ao invés de fazer uso de temas e da inspiração mitológica, o objetivo de Courbet era retratar a vida e os problemas reais de seu tempo. Desse modo, o discurso pictórico de Courbet e dos realistas em geral assume o trabalho como peça central de sua visão de mundo. Ao tratar de forma individual tais eventos mundanos, tal como ocorrem, estes artistas fazem a opção de romper com as narrativas convencionais da arte acadêmica de então. Assim, a figura do próprio trabalhador, para além da arte, é repensada, à medida em que expressa a própria complexidade histórica do cenário europeu no período. Chiarelli salienta que, muito embora a obra de Gustave Courbet, comprometido com a realidade social francesa, tenha sido a mais radical, entre todas as iniciativas realistas do período, efetivamente não é exclusiva neste contexto.

Antes e em paralelo a tal produção, era possivel perceber na cena inglesa e francesa um interesse crescente de certos artistas em eleger paisagens campestres ou suburbanas, trabalhadores das classes sociais menos favorecidas do campo e da cidade, como temas para suas obras (Chiarelli, 2007, p. 217).

Tais iniciativas não ficaram restritas ao contexto europeu. No Brasil, Almeida Júnior (1850-1899) ${ }^{7}$ é o artista que melhor assimilou o legado realista de Courbet, articulando-o a uma abordagem regionalista, e introduzindo temáticas até então inéditas na produção acadêmica brasileira.

Tal como Courbet, Almeida Júnior concede amplo destaque a personagens ordinários e anônimos. Dedicou-se especialmente a criar um vívido retrato da cultura caipira, sobretudo paulista, num viés real-naturalista, em detrimento da monumentalidade até então em voga no ensino artístico oficial. Ademais, o artista foi capaz de criar uma impressão de proximidade entre o espectador e a cena retratada, constituindo-se um ambiente intimista. Do conjunto de sua obra, destacam-se as composições de caráter regionalista, que retratam a arquitetura de paua-pique e o homem do interior, de barba rala e pés descalços, dentre as quais $O$ derrubador brasileiro (1879) (FIGURA 06).

Exposta no Museu Nacional de Belas Artes, no Rio de Janeiro, a referida obra é a primeira de sua autoria a apresentar temática nacional. "Esta obra foi produzida no período em que o pintor estava na Europa e a paisagem que foi pintada de memória, difere das demais obras regionalistas que foram pintadas a partir da observação do real" (Frias, 2013, p. 31).

\footnotetext{
O pintor, de origem humilde e proveniente do interior do Estado de São Paulo, iniciou seus estudos na Academia Imperial de Belas Artes do Rio de Janeiro. Mais tarde, em função de uma bolsa de estudos cedida pelo Imperador, ingressou na Escola de Belas Artes de Paris. Segundo Frias (2013, p. 30), sendo um pintor de formação acadêmica, sua produção pictórica caracterizava-se pela excelente qualidade técnica, mantida em toda sua trajetória.
} 
FIGURA 06 - O derrubador brasileiro (1879), óleo sobre tela de Almeida Júnior.

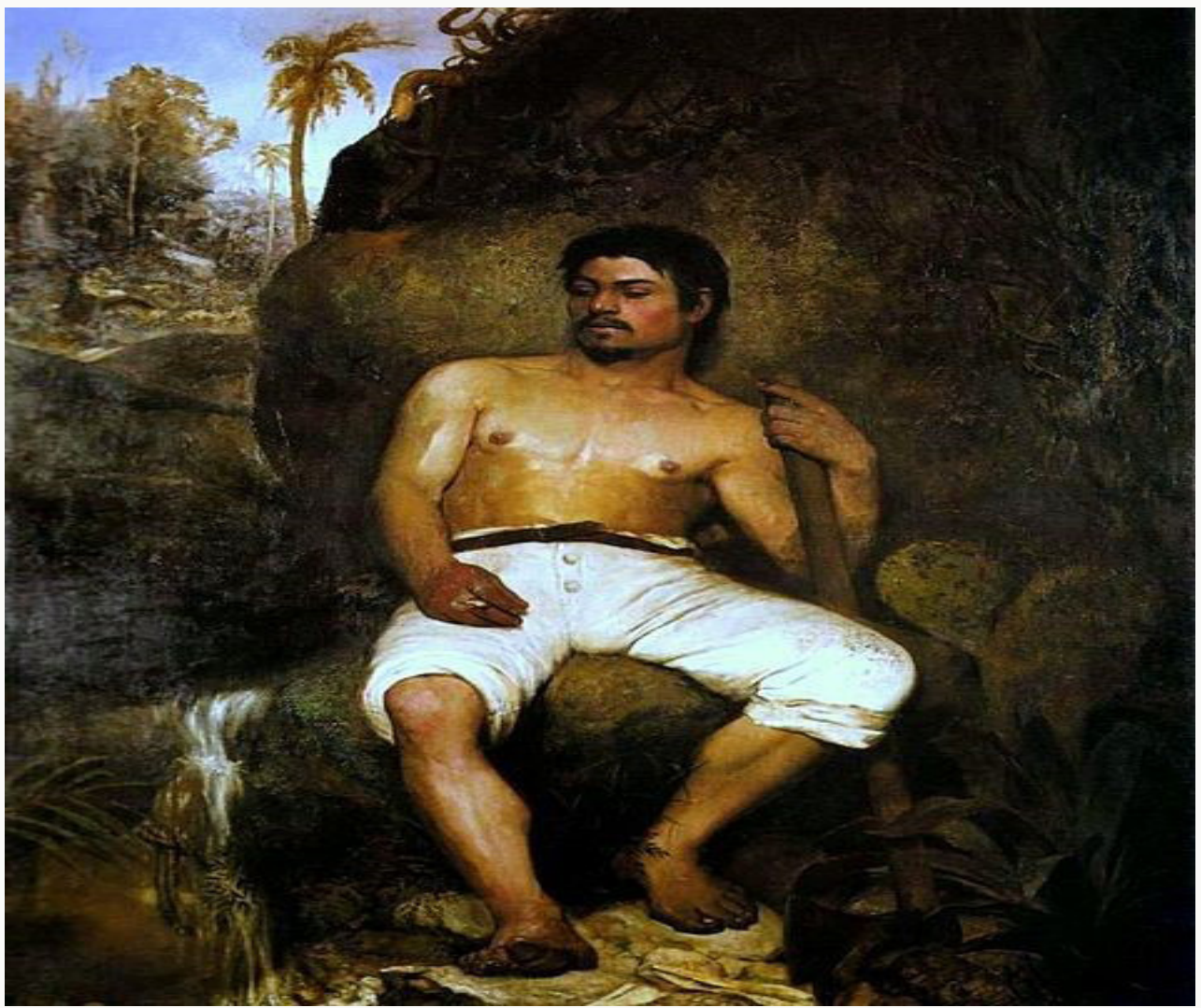

FONTE: Acervo Online. Museu Nacional de Belas Artes

Ainda que os traços acadêmicos de sua formação não sejam totalmente abandonados, sua plástica é autêntica e inovadora, à medida em que são mesclados elementos do realismo europeu, à temática tropical, sem prescindir de delicado refinamento técnico, para a concepção de uma imagem efetivamente nacional. Nas palavras de Souza:

Pintada em Paris em 1879, trai, na presença do rochedo, a concepção grandiosa do Realismo; mas nos demais elementos, nos coqueiros, na natureza tropical do pequeno trecho de paisagem, nas feições mestiças da figura, exprime a nostalgia da pátria distante. É nosso, sobretudo, o jeito do homem se apoiar no instrumento, sentar-se, segurar o cigarro entre os dedos, manifestar no corpo largado a impressão de força cansada, a que Candido Portinari parece não ter sido insensível (Souza, 1974, p. 120).

O personagem ao centro da composição traduz uma identidade, seja brasileira, seja especificamente interiorana. Esta se expressa tanto nos traços faciais nitidamente mestiços do homem de pele bronzeada e barba rala (ainda que o modelo utilizado tenha sido um italiano); 
quanto em sua pose displicente, marca de uma força física em estado de repouso: apoia-se no machado, pernas abertas, os pés repousando à vontade, palheiro entre os dedos, costas reclinadas contra a rocha. São elementos que caracterizam tanto a atividade do personagem enquanto derrubador, quanto a sua masculinidade, associada aovigor físico e, talvez, certa brutalidade, em sua caracterização e gestualidade.

Este corpo forte e em repouso transmite também uma sensualidade latente na ênfase concedida pelo artista aos contornos da musculatura, ressaltada com brilhos de suor, e ao enquadramento, que situa os músculos abdominais e o baixo-ventre do trabalhador como ponto fulcral da figuração. Sobre esta sensualidade na tessitura da composição, Perutti argumenta que a luminosidade da própria tela contribui para a construção discursiva em questão: "as pernas abertas da personagem [...], ocupando uma área significativa na pintura, forma uma espécie de grota, com espaços bem delimitados geometricamente e que conferem às partes baixas de seu corpo um grande destaque na cena" (Perutti, 2007, p. 211).

O cenário ao redor é uma declaração identitária tão forte quanto a figura humana: coqueiros, cactos, bromélias e samambaias emolduram o derrubador, construindo uma paisagem acima de tudo brasileira. Ao mesmo tempo, a obra é tributária do estilo paisagístico anteriormente visto em Courbet, em sua composição Os quebradores de pedra. O céu ao fundo denota, associado ao brilho do corpo, a importância do trabalho com a luz para o artista: embora trate-se de uma obra composta em estúdio, o tratamento da luminosidade é dotado de nuances e contrastes, podendo ser classificada como proto-impressionista.

Dentre as questões que permeiam a produção regionalista de Almeida Júnior, uma das mais complexas é a questão do clareamento da paleta de cores apresentado nestas obras. As cores usadas nas obras regionalistas são mais vivas, o artista altera alguns tons de cores de sua paleta tornando-a mais clara. Uma das explicações dos críticos para o uso das "novas cores" estaria relacionada à representação da luminosidade natural das paisagens que o pintor retratou, que seriam reflexos da natureza tropical. Outra explicação seria a influência da "luz impressionista" com a qual o pintor teria tomado contato durante o período em que esteve em Paris (Frias, 2013, p. 33).

Almeida Júnior aprimora a representação do caipira e/ou do homem trabalhador em obras subsequentes, como Caipira picando fumo (1893) e Amolação Interrompida (1894). A partir destas e de outras obras, de acordo com o que postula Chiarelli, Almeida Júnior pode ser considerado como o elo problemático, unindo a paisagem física local à paisagem humana. Deste modo, para o autor, as pinturas "caipiras" do artista seriam "uma espécie de arrolamento estético-documental do que o paulista do final do século XIX supostamente deixava de ser um miserável, vivendo em condições degradantes, submetido a uma apatia pouco produtiva" (Chiarelli, 2009, p. 138). Talvez $\circ$ artista do interior paulista tenha pretendido preservar nas telas esse tipo humano supostamente em extinção, ameaçado ora pelos imigrantes cada vez 
numerosos, ora pelos "novos paulistas", entretidos com a prosperidade da economia cafeeira.

Talvez seja o que acontece com a representação dos trabalhadores por parte de Del Debbio nas construções tumulares, tanto da Família Rizkallah Jorge quanto da Família Demétrio Calfat, a ser analisada adiante, ambas do final da década de 1950. Especificamente, no que diz respeito à arte funerária, a presença dos trabalhadores constitui indicativo de afirmação da classe burguesa, muitas vezes proveniente dos fluxos imigratórios do início do século XX. No caso de Rizkallah Jorge, as alegorias relacionadas ao labor se propõem a reafirmar seu protagonismo no cenário paulistano. Para o imigrante, o trabalho, seja agrícola, comercial ou industrial, era com frequência a alternativa para a ascensão social e econômica.

Com base em Scott (1995, p. 93), questiona-se que compreensão de gênero se inscreve aqui. A presença das representações de labor nos túmulos, por intermédio dos atributos e/ou dos trabalhadores, é uma forma de perenização enobrecedora dos sepultados, perspectiva que contribui para a mitificação do burguês, sobretudo do imigrante burguês - é uma representação de masculinidade expressiva das relações de poder da sociedade paulistana do período, que vê (ou deposita) no imigrante um modelo de homem a ser seguido.

Absorvidos pela sociedade brasileira, na grande maioria dos casos os imigrantes experimentam uma relação entre o homem e a terra e entre o trabalhador e o proprietário que havia se tornado difícil no país de origem [...]. Em consequência, a interpretação que o próprio imigrante desenvolveu sobre a acumulação primitiva, a expropriação, a expulsão e a migração para a sociedade brasileira assumiu um conteúdo conservador. A sociedade de adoção aparentemente recriava relações que estavam desaparecendo no país de origem e se apresentava para ele como a "boa sociedade", pois os que o expulsaram da terra e que se beneficiaram com a expulsão não estavam aqui. A sociedade brasileira, de certo modo, oferecia-lhe de volta o que lhe haviam tirado no país de origem (Martins, 1979, p. 119).

Deste modo, a via do trabalho assume a função de sintetizar a identidade do imigrante/ trabalhador (mesmo para os já enriquecidos e que efetivamente não trilharam necessariamente uma trajetória camponesa e/ou operária): são as terras tropicais que permitiram a ascensão social destes personagens, e é esta memória que deverá ser perenizada nas edificações tumulares. Conforme pontuado anteriormente, os imigrantes foram convertidos em modelos de trabalhadores a serem seguidos e, por consequência, modelos de masculinidade, vistos como sóbrios e sempre dispostos ao trabalho árduo e à vida difícil, sacrifícios estes que seriam compensados posteriormente (Chalhoub, 2008, p. 77). Assim, a representação do trabalho é diretamente conexa à concepção de masculinidade, claramente reforçada a partir da consolidação do sistema capitalista. Nas palavras de Nolasco:

A partir da Revolução Industrial, os valores e a dinâmica capitalista passam 
cada vez mais a reforçar e a definir os padrões de comportamento masculinos. Desejar construir um patrimônio e ter status e poder podem ser parâmetros tanto para analisarmos os valores do sistema capitalista como para identificarmos as principais diretrizes que um homem deva tomar para si. É pela determinação da função do que é o trabalho, segundo a especificação capitalista, que estará sendo mantida a direção para os comportamentos e projetos homens (Nolasco, 1993, p. 52).

O trabalho, portanto, assume a função de caractere identificador do conceito de homem e masculinidade. $O$ autor ainda pontua que, para os homens, o trabalho equivale ao significado que a maternidade assume para as mulheres e para a feminilidade: a única possibilidade de realização, aquilo que identifica um homem como tal. Conforme Martins (1979, p. 150), no caso brasileiro, o paternalismo e o populismo burgueses estão diretamente fundados nessa concepção do trabalho masculinizado, do homem protetor, o que favorece a consolidação da ideologia do trabalho dignificante, legitimando a exploração do trabalhador. Os símbolos podem ser os mesmos do passado, conforme pontua Scott (1995, p. 93), mas são os processos políticos e sociais, temporal e espacialmente localizados, que determinam os resultados e/ou as leituras que irão prevalecer. Em outras palavras, a categoria "homem" é aqui preenchida com os atributos de trabalho, para construir um ideal de masculinidade específico e consoante com o contexto paulistano.

\section{O caminho viril: força física e trabalho como síntese mitificadora}

Na mesma linha simbólica, o escultor Antelo Del Debbio (1901-1971) concebeu outro conjunto tumular, que apresenta o tema do trabalho em sua tessitura. É a construção da Família Demétrio Calfat (FIGURA 07).

A data da edificação do túmulo da Família Demétrio Calfat no Cemitério da Consolação é imprecisa, visto que a data de sepultamento de Demétrio Calfat é desconhecida - provavelmente remonta à década de 1950. É sabido que a Família Calfat, de origem libanesa, desempenhou relevante papel no processo de industrialização de São Paulo. O libanês Miguel Calfat (18811957) (irmão de Demétrio Calfat) teria emigrado para o Brasil em 1901, tendo inicialmente se dedicado à atividade comercial em Dourados. Mais tarde, mudou-se para São Paulo com os irmãos Elias, Demétrio e Gabriel, ali fundando a firma comercial e industrial Elias Calfat \& Irmãos, empresa têxtil. As atividades comerciais ligadas a este ramo foram sendo ampliadas pelo grupo familiar ao longo dos anos. 
FIGURA 07 - Túmulo da Família Demétrio Calfat (c. 1950), esculturas em bronze de Antelo Del Debbio, Cemitério da Consolação.

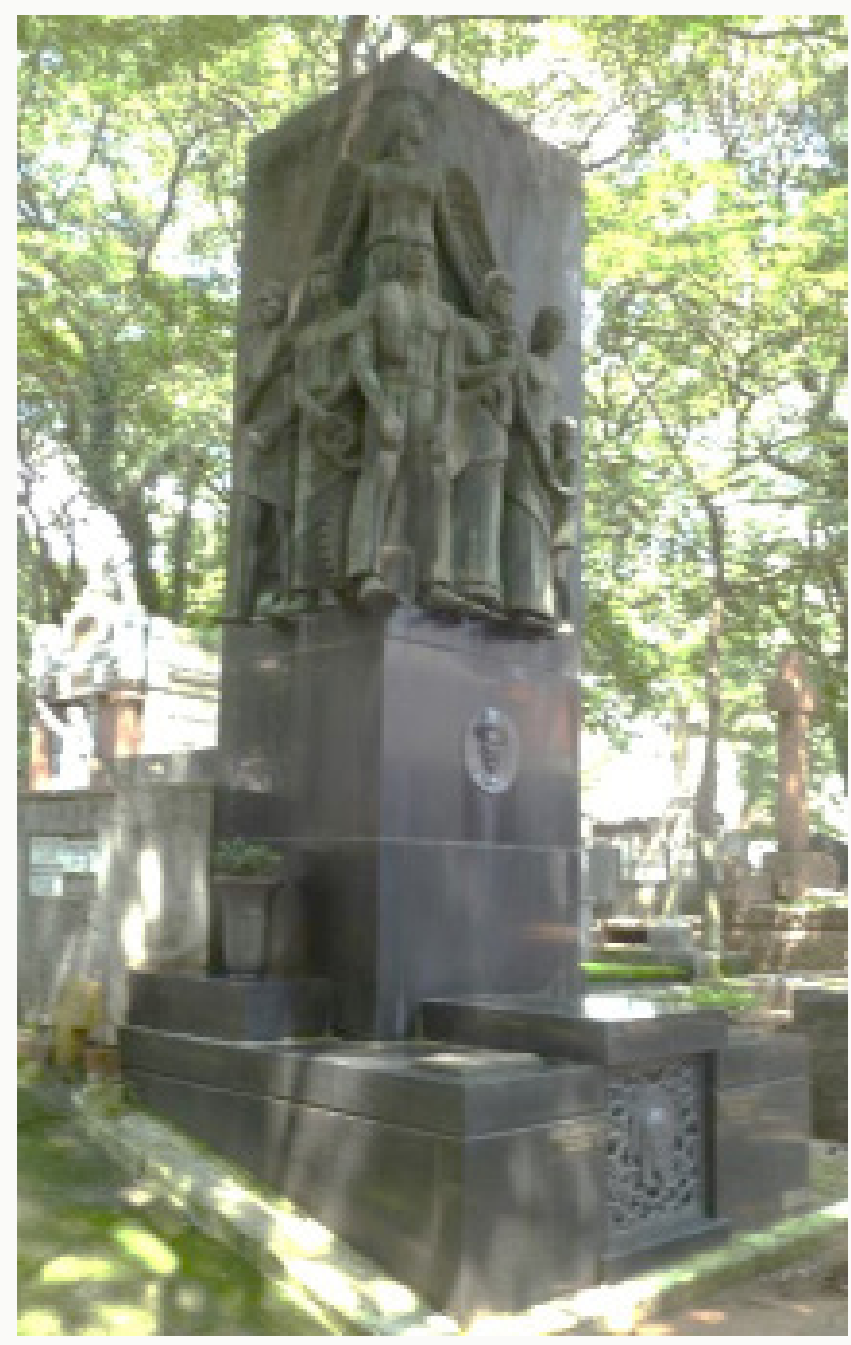

FONTE: acervo da autora, 2014.

O complexo tumular Calfat é uma estrutura monumental, predominantemente verticalizada, revestida por placas de granito preto polido, estabelecida sobre uma grande base, do mesmo material. Em um plano elevado está afixado um conjunto escultórico confeccionado em bronze, acompanhando o ângulo formado pelas faces frontal e lateral esquerda da construção, sem sustentação inferior. O grupo é formado por cinco figuras humanas e uma figura angelical, sem contar os infantes que as acompanham (FIGURA 08).

Na parte frontal, observa-se o busto em baixo relevo, retratando Demétrio Calfat. Sob uma figura angelical de contornos femininos, encontram-se cinco personagens, além dos infantes. Da direita para a esquerda, uma mulher acompanhada por um menino, ao seu lado uma segunda mulher, segurando um bebê em seu colo, um homem com o torso nu, posicionado no exato ângulo frontal esquerdo, ladeado por outra figura feminina e um segundo personagem masculino, também com o torso nu, fechando o grupo. A composição tecida por Del Debbio 
exalta precisamente três valores fundamentais à burguesia: a religião, a família e o trabalho.

FIGURA 08 - Detalhe do Conjunto Escultórico do Túmulo da Família Demétrio.

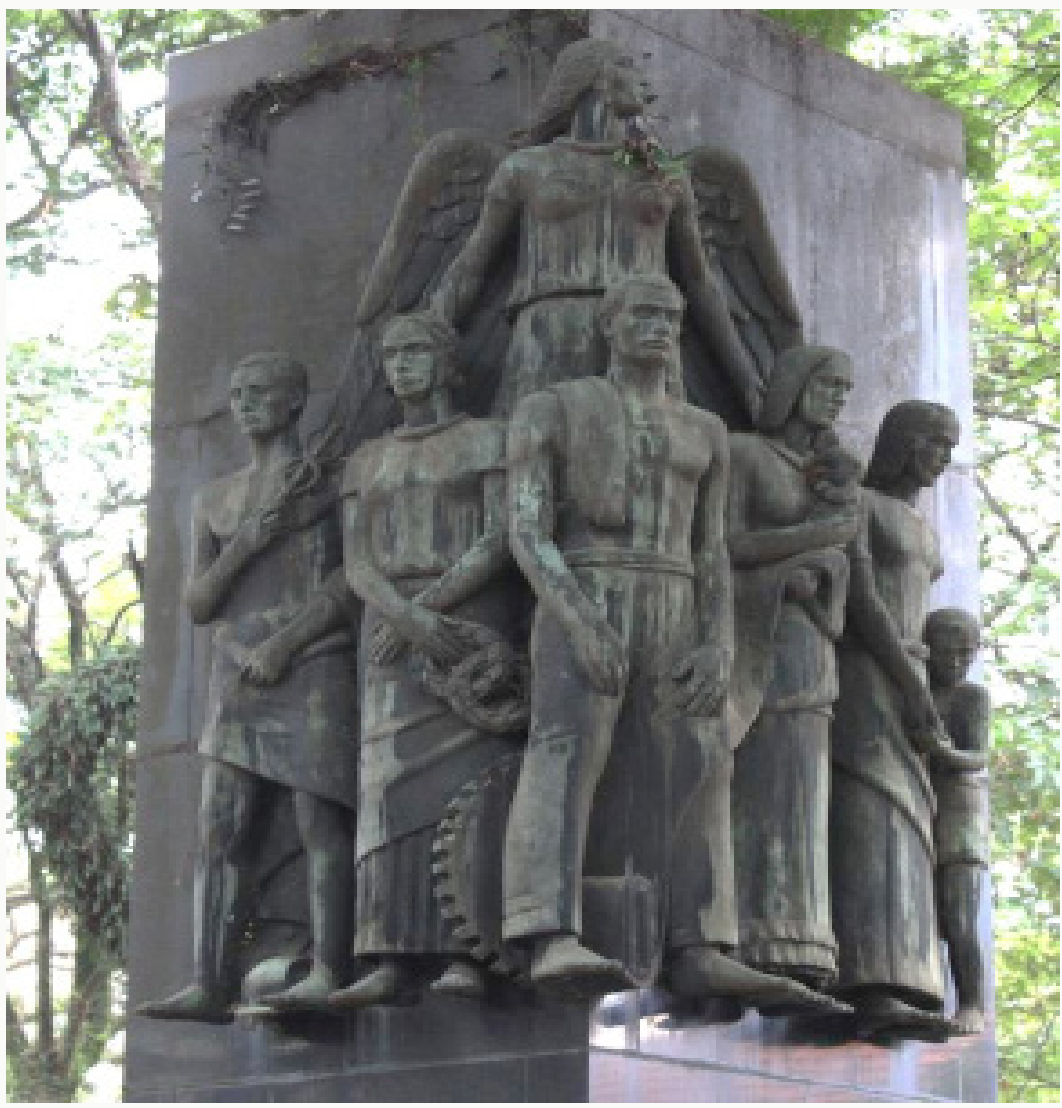

FONTE: acervo da autora, 2014.

Favaro observa uma relação intrínseca entre a ampla transformação econômica, via industrialização e a intensa promoção dos valores burgueses, quais sejam: "[...] a família (base da força-trabalho, de um lado, e da concentração do capital, de outro), a autoridade paterna e, evidentemente, do tão decantado, incansável, incondicional e insubstituível amor materno" (Favaro, 2002, p. 135). As duas figuras femininas apresentadas na parte frontal da composição tumular (FIGURA 09) representam a valorização da família: acompanhadas por duas crianças, são figurativas da família burguesa e, sobretudo, do amor materno. Ambas as figuras são representadas em uma pose protetiva, em relação ao menino e ao bebê - parecem representar a maternidade.

Segundo Marquezan (2006, s/p.), na sociedade pré-moderna a família não tinha função afetiva, oportunizava a ajuda mútua entre um homem e uma mulher numa época em que isolados tinham chances reduzidas de sobrevivência. Neste contexto, a concepção do conceito de infância era ainda incipiente. Foi a propriedade privada que ensejou a monogamia, e ambas se constituíram nos principais fatores que geraram a instituição familiar moderna, como forma de assegurar a transmissão da herança aos descendentes. Por sua vez, a família burguesa estruturou-se no período entre o final do séc. XVIII e início do séc. XIX, constituída pela nova classe dominante, 
cujos padrões de relacionamento familiar e social diferenciavam-se claramente dos modelos então vigentes.

FIGURA 09 - Detalhe do Conjunto Escultórico do Túmulo da Família Demétrio.

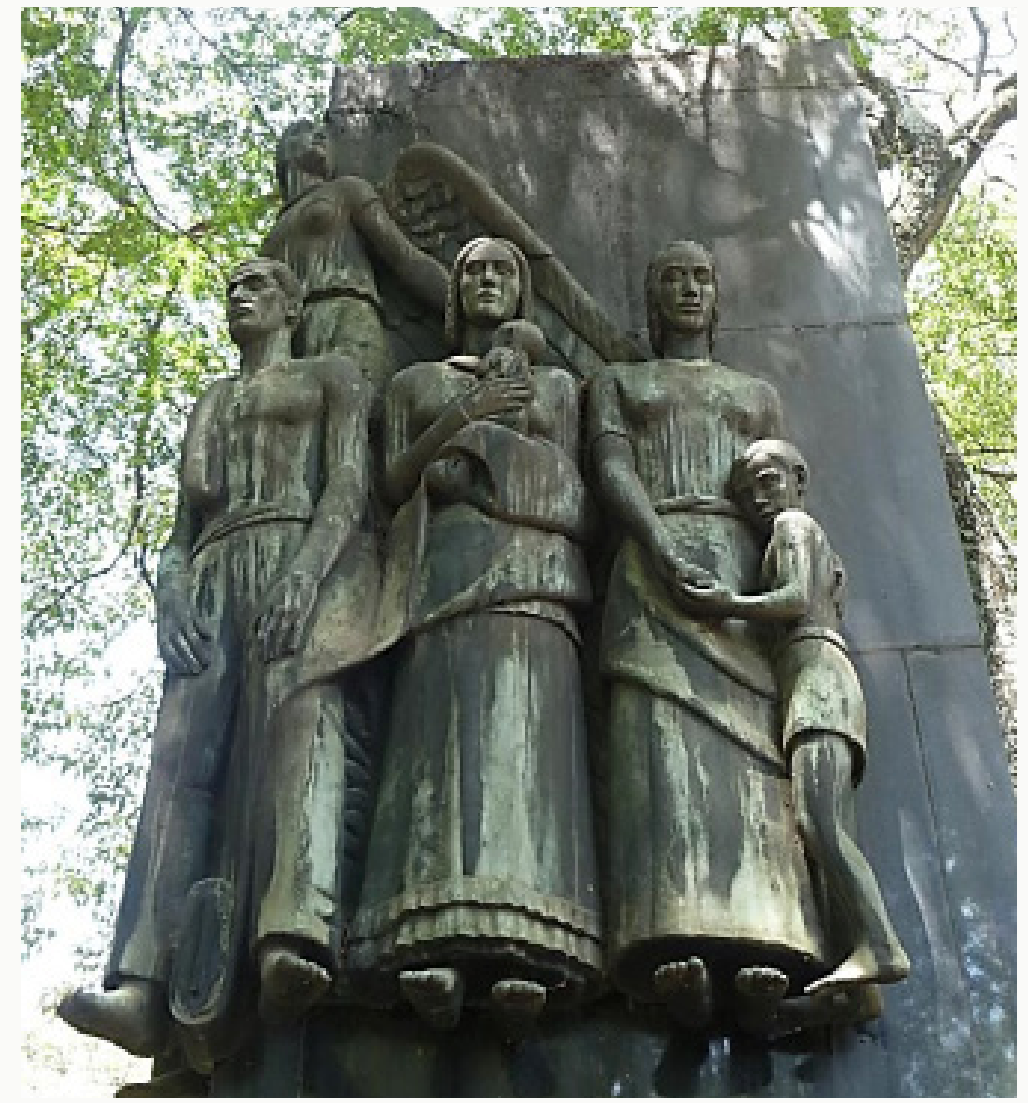

FONTE: acervo da autora, 2014.

A criança abraçada à mãe sugere esta perspectiva burguesa de amor familiar, muito embora a representação do homem posicionado centralmente, com vestuário de trabalhador e pés descalços não corresponda à caracterização tradicional de um burguês. Ainda assim, a metáfora é mantida. Trata-se de uma metáfora expressiva das relações de gênero que, em sua ambiguidade enquanto categoria, ampara-se em domínios, identidades e comportamentos transitórios, expressivos de determinados interesses (Piscitelli, 2004, p.186). Neste caso, representar o homem como trabalhador assume um sentido ideológico crucial: a posição social do burguês é uma consequência da existência do homem enquanto trabalhador, sua riqueza advém de sua função e posição. Nas palavras de Matos:

No contraponto da esposa, dedicada, boa mãe, responsável pela "encantadora paz do lar", esboça-se o modelo de pai, associando-o à masculinidade, fortalecendo a imagem de um pai que tem de ser provedor, do ponto de vista material, chefe autoritário, fundador da família, tudo deriva dele e tudo vai para ele, pai protetor e temido, com seus olhos 
fiscalizadores, defendendo a disciplina, a moral e a punição, baseado no cumprimento dos seus deveres e na sua autoridade, querido e respeitado por todos (Matos, 2001, p. 44).

O homem ao centro, situado diante do anjo (FIGURA 10), está com o torso nu e apresenta uma pose ereta, hierática. A figura angelical parece acolher todos os personagens, desempenhando uma função protetora. Há um rolo de tecido entre as pernas, uma faixa do material esticando-se sobre sua perna direita e subindo até unir-se às dobras do pano no qual a mulher à sua direita segura o bebê. Há, ainda, uma dobra de tecido sobre o ombro esquerdo da figura central. O ritmo composicional parece ser construído para dar a impressão de continuidade, que vai da figura masculina até à mulher e o menino, também com panejamentos envolvendo-os.

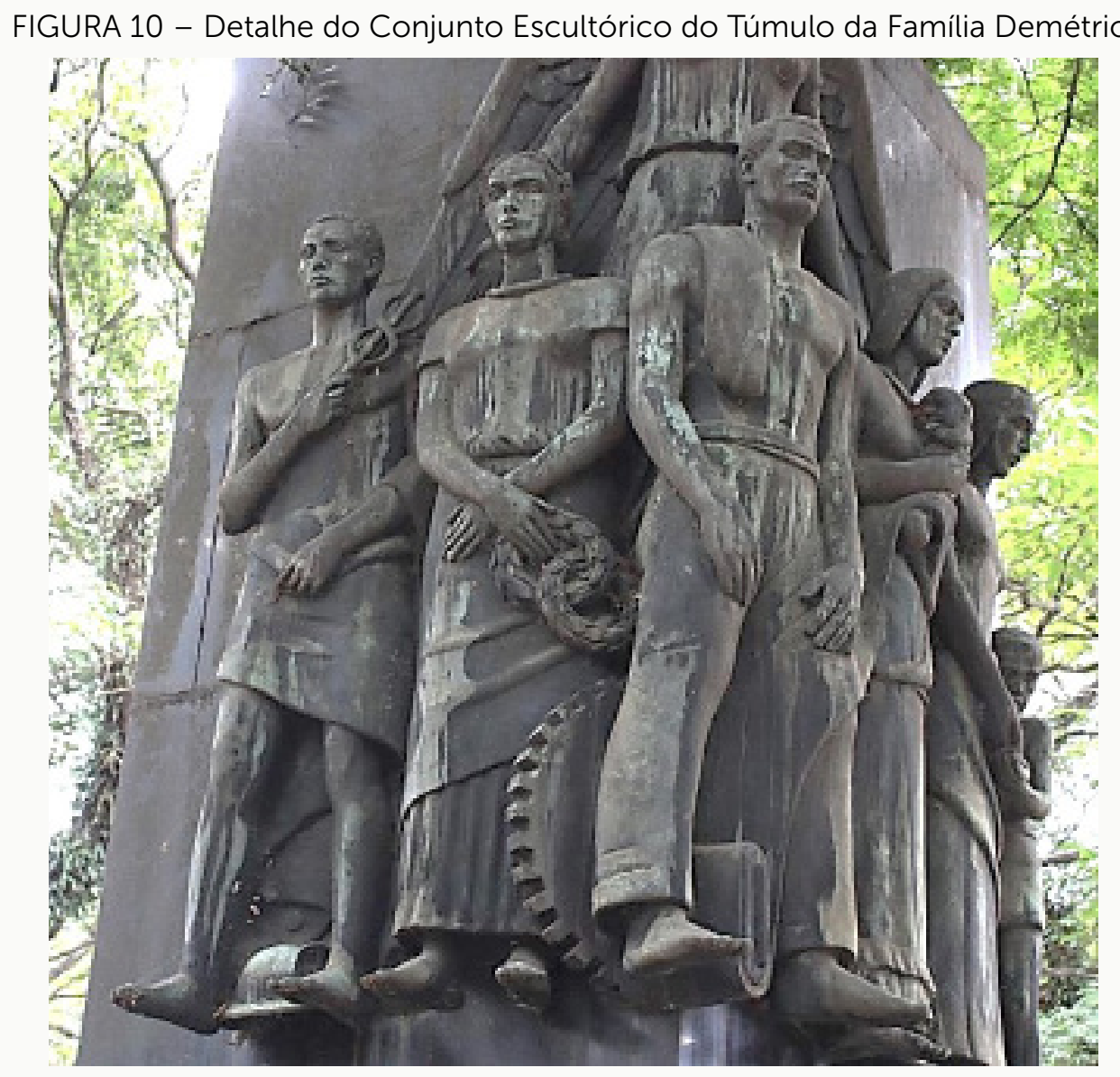

FONTE: acervo da autora, 2014.

Considerando o envolvimento da família Calfat com o comércio de têxteis, o rolo de tecido adquire um sentido relevante, envolvendo os personagens em dobras do material. Este sentido é especialmente forte, dada a presença, ao lado do personagem central, da roda dentada, símbolo do trabalho; combinados, os dois elementos, tecido e roda dentada, 
discursam sobre o ramo de atividades que inseriu a Família Calfat na sociedade paulistana. À esquerda, as figuras são concebidas com atributos divinos. No extremo da composição, uma figura de Hermes, brandindo um caduceu na mão esquerda, com um capacete alado a seus pés, uma vez mais, traz o motivo têxtil enrolado em torno de sua cintura. Na Grécia Antiga, Hermes era cultuado como deus protetor dos viajantes e, também, do comércio. O caduceu, o báculo segurado pelo deus, em torno do qual duas serpentes estão entrelaçadas, pode ser utilizado como síntese simbólica do valor do comércio. Mais uma vez observa-se, no conjunto simbólico do túmulo, o discurso burguês, relativo ao valor do trabalho e da atividade mercantil. Completa a composição uma terceira imagem feminina, desta vez coroada com louros e carregando duas guirlandas, simbologia associada ao heroísmo e à saudade - possivelmente uma forma de coroar as conquistas do sepultado Demétrio Calfat e salientar sua memória. O conjunto apresenta uma plástica modernista, na qual a configuração dos personagens é mais volumétrica e hierática que realista. A expressividade da composição é obtida por meio da conjugação da monumentalidade e do geometrismo das formas. É o que pode ser observado nas pinturas de Candido Portinari (1903-1962), artista que também fez uso da lente modernista, conforme apreende-se da análise de O lavrador de café (1934) (FIGURA 11).

FIGURA 11 - O lavrador de café (1934), óleo sobre tela de Candido Portinari, MASP.

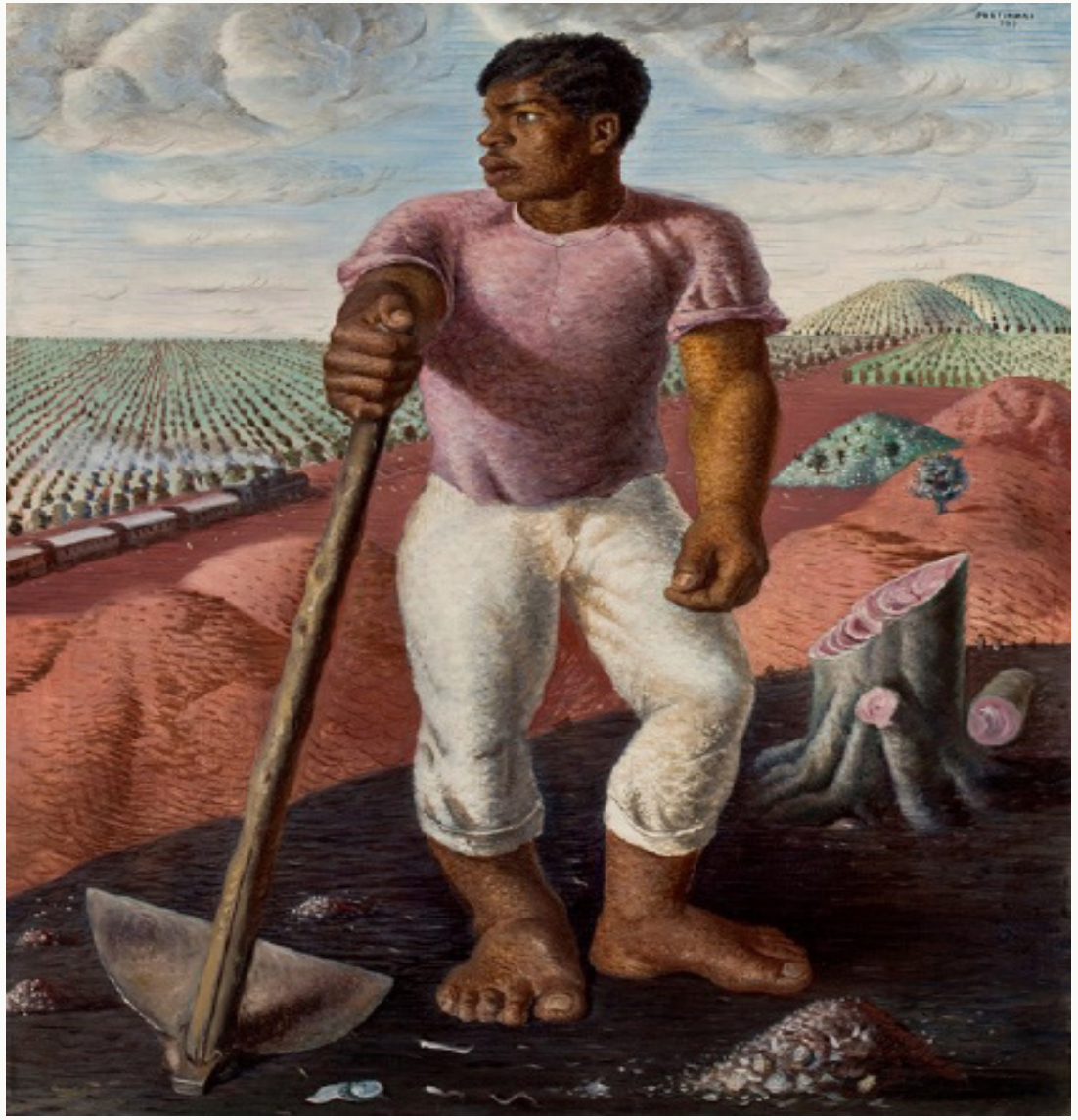

FONTE: Acervo Online. 
Assim como em O derrubador de Almeida Júnior, Portinari situa um trabalhador no centro de sua composição e também dá destaque a seus dotes físicos, salientando sua relação com o ambiente. Utilizando-se de distorções expressionistas, Portinari enfatiza a robustez dos braços e pernas do lavrador de café, dotando-o de mãos e pés desproporcionalmente grandes, em referência ao papel desempenhado pelo lavrador: de trabalhador braçal, valorizado sobretudo por sua força física. O personagem se apoia sobre a enxada, e lança um olhar grave para o lado esquerdo. Ele é representado de forma altiva, monumental.

O personagem é emoldurado por um forte cenário nacional; aqui, todavia, não é o componente bucólico da paisagem brasileira que ganha destaque, mas o cenário econômico, expresso nas atividades de derrubada de matas para o plantio, na cultura do café em amplas extensões de terra, e na ferrovia, signo de modernidade que serve ao propósito de transportar esta nova fonte de riqueza agrícola. No entanto, no discurso pictórico de Portinari, está o titânico trabalhador agrícola, mestiço e descalço, a espinha dorsal desta grande máquina econômica. Portinari não pretende preservar a imagem do caipira, como fizera seu antecessor Almeida Júnior; talvez esse personagem não possa mais ser preservado, dada a conjuntura nacional contemporânea ao pintor modernista. O que se destaca, em contrapartida, é propriamente a contradição entre a economia progressista de São Paulo, de um lado, e os pés descalços do lavrador de café, do outro. Chiarelli pontua que a pintura em questão é uma versão modernista d'O derrubador brasileiro, que faz ressurgir o antigo lavrador:

antes cansado da lida, agora em pé e altaneiro, ligado à terra não apenas pela deformação expressiva dos pés que aparecem plantados ao solo, mas também pela maneira como segura a ferramenta de trabalho, extensão do seu corpo, indice de sua função no mundo (Chiarelli, 2007, p. 131).

Portinari, segundo o autor, constrói um discurso especifico acerca da relação do homem com o ambiente: a natureza é o lugar do trabalho do homem - de ação direta e de transformação. "É de se reparar como a figura do lavrador olha ao longe, orgulhoso, e, ao mesmo tempo, aparentemente alheio à locomotiva que, ao longe, não ameaça seu papel de protagonista em mais essa alegoria positiva do país" (Chiarelli, 2007, p. 132). A postura do personagem - altiva, orgulhosa; é executada a partir da instrumentalização de vários aportes dos estilos artísticos precedentes ao artista, para construir um discurso apologético do Brasil, entrevisto a partir do lavrador. Em outras palavras, o lavrador é a síntese discursiva do que é o Brasil.

Segundo Fabris, a arte e a poética de Portinari poderia ser abreviada em uma única preocupação: o homem. Em busca do homem "real", o artista modernista construiu um discurso autêntico: "uma monumentalidade escultórica, uma corporeidade pura, que se transforma simultaneamente em visão do homem social" (Fabris, 1996, p. 36). O lavrador desfruta de deformação expressiva na definição do corpo e do rosto, resultando numa pintura antinaturalista, tratamento difundido entre os modernistas, por vezes referida como "deformação expressionista". Entretanto, esta opção não é sem propósito em Portinari, mas possui a intenção de sublinhar a 
monumentalidade da forma.

A deformação expressionista, que em alguns artistas chega a ser agressiva e ofensiva (por exemplo, Nolde), não é deformação ótica: é determinada por fatores subjetivos (a intencionalidade com que se aborda a realidade presente) e objetivos (a identificação da imagem com uma matéria resistente ou relutante) (Argan, 2008, p. 240).

Em O lavrador de café, portanto, uma síntese se constrói por intermédio de tal deformação: o exagero das formas busca efetivamente salientar o papel do trabalhador na composição do Brasil, com todas as suas contradições. Não se vê um trabalhador sofrido ou fustigado pelo trabalho árduo, mas uma figura forte que tem na enxada - prolongamento de si, sua própria identidade, sua masculinidade. Isso porque, conforme defende Butler (2013, p. 26), identidade e gênero são fenômenos contextuais - é um gesto de performance que produz significados. Pés e mãos salientam a vinculação do artista com a temática social. A deformação expressionista busca construir a síntese da obra e o vínculo entre o homem e o trabalho, como se observa também em Café (1935).

Em Del Debbio, a exemplo de Portinari, por intermédio do geometrismo e da volumetria das formas corpóreas dos personagens, parcialmente desnudos, ganham ênfase os braços e as pernas musculosas, os pés descalços e os braços fortes, signos da vida ganha por meio do esforço físico e do corpo condicionado à labuta. Por intermédio da linguagem expressionista, conjugada à força emotiva e psicológica de sua deformação proposital, Portinari denunciou as contradições do mundo do trabalho. Por sua vez, Del Debbio constrói um discurso dignificante e enobrecedor do trabalho, tecido pela lente modernista. Pela via da monumentalidade, as figuras expressam força latente, não obstante a pose sóbria e hierática, com o olhar voltado à linha do horizonte.

A indumentária do trabalhador representado por Del Debbio e afixado ao centro do conjunto escultórico é composta por uma calça simples, de camponês ou operário. Descalço, sua caracterização assemelha-se à do escravo do período colonial, e não a de um operário ou proletário urbano. Todavia, a roda dentada que acompanha o trabalhador define a contemporaneidade da composição: faz referência ao contexto industrial. O escultor italiano Rizzoli Pasquale (18711953) interpretou o tema do trabalho, também fazendo uso deste atributo. É um dos elementos centrais da obra concebida pelo artista para a sepultura da Família Ronzani (1904) (FIGURA 12), constituinte do acervo do Cemitério Monumental de Certosa, em Bologna, na Itália. 
FIGURA 12 - Túmulo da Família Ronzani (1904), escultura em mármore de Rizzoli Pasquale, Cemitério Monumental de Certosa.

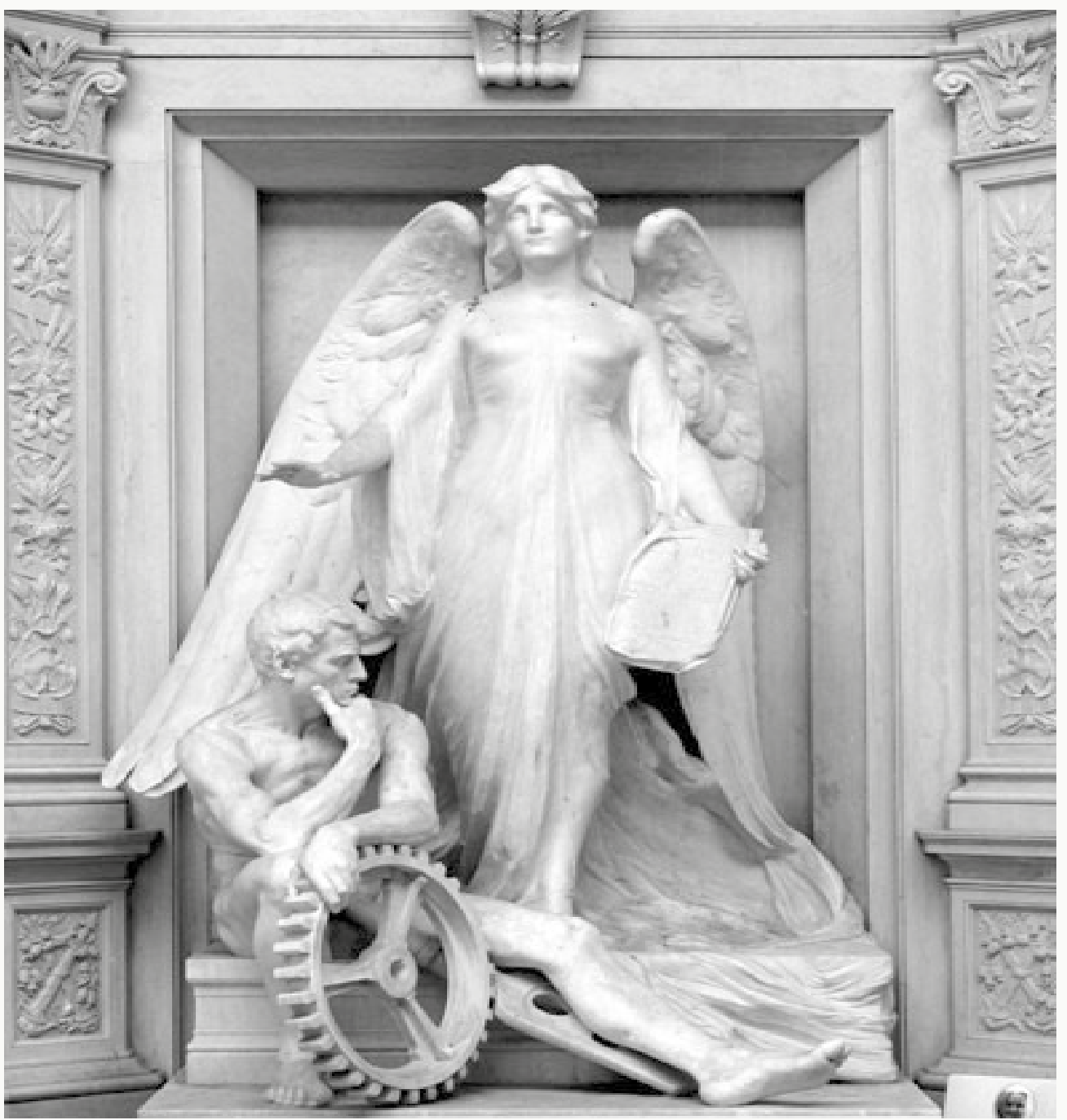

Fonte: PESCI, 1998, p. 281.

Sob encomenda de Alessandro Ronzani (?-1926), Pasquale compôs um monumento moderno, no qual a rigidez do grande anjo ao fundo se contrapõe à vivaz representação neomichelangelesca da figura masculina, posicionada na parte inferior da composição. Nu, o homem apoia-se sobre uma monumental roda dentada; o corpo musculoso e forte se contrapõe à expressão contida e quase pesarosa. A obra se insere na perspectiva verista e realista do início do século XX, na Itália, correspondente ao momento em que a afirmação da sociedade industrial havia favorecido a formação de uma alta burguesia capitalista. Esta classe via na criação da "tumba de família" o monumento da própria autocelebração e a possibilidade de manifestar o sucesso obtido (Pesci, 1998, p. 252-253).

Especificamente quanto ao uso da roda dentada como símbolo industrial, observa-se que este atributo, juntamente com a corrente, é o principal meio utilizado na indústria para 
transmitir potência e movimentar mecanismos nos quais são requeridos deslocamento positivo e posicionamento perfeito. É o elemento que transmite a ideia de eficiência industrial. Se a bigorna simboliza precisamente o trabalho individual e braçal, a roda dentada, por sua vez, é um sintoma da consolidação do capital e do trabalho industrial, para o qual é necessário mais do que a força motriz do próprio trabalhador. Sua função nestes túmulos, ao lado dos trabalhadores, é evocar tanto a esfera industrial quanto a própria classe burguesa, da qual os sepultados fazem parte, identificados por meio do trabalho.

Segundo Martins (1979, p. 146), o advento do trabalho livre separou a pessoa do trabalhador de sua capacidade de trabalho, de sua força de trabalho. Os mecanismos ideológicos que então legitimavam a sujeição da pessoa e a desigualdade de que ela provinha perderam sua eficácia, sendo substituídos por novas engrenagens. A sujeição da pessoa foi substituída pela sujeição do trabalho ao capital.

Logo, o mito anterior da desigualdade de origem entre as pessoas já não servia para justificar e legitimar as novas relações, baseadas na compra e venda de força de trabalho. Através destas ultimas instituía-se a igualdade formal entre o burguês e o operário. Como, então, sendo eles formalmente iguais, um ficava cada vez mais rico e o outro não? (Martins, 1979, p. 146).

É o reconhecimento do trabalho, enquanto fonte de riqueza que o legitima na era do capital e cria um novo ethos. Efetivamente, o burguês precisa da força de trabalho do trabalhador para enriquecer, e este precisa do emprego para ganhar dinheiro e comprar a terra que representará seu enriquecimento. Cria-se um aparato ideológico segundo o qual todos os indivíduos têm condições iguais de progresso. Segundo Martins (1979, p. 147), com frequência o imigrante é identificado a partir desta ótica, como detentor de uma ética diferenciada para com o trabalho, uma espécie de privilégio cultural, da qual o trabalhador brasileiro era excluído. Apesar de equivocada, com frequência esta ótica do trabalho como fonte do progresso individual, definidor do caráter, é utilizada como identificador dos imigrantes, inclusive na arte funerária.

A industrialização brasileira encontrou no mito do burguês enriquecido pelo trabalho e pela vida penosa um ingrediente vital. Ao contrário da burguesia agrária, que tivera de enfrentar o problema da produção e elaboração da ideologia de transição do trabalho escravo para o trabalho livre, a burguesia industrial já encontrou prontas a justificativa e a legitimação da exploração do trabalhador, ainda que com base numa concepção pré-capitalista de trabalho independente (Martins, 1979, p. 150).

Ideologicamente, o trabalho independente e o esforço das próprias mãos constituem as fontes para o sucesso do burguês - mais uma vez, trata-se de um discurso metafórico das relações de gênero, ao associar o sucesso do homem ao seu labor, constrói-se um modelo 
de masculinidade ideal. É este o discurso que está expresso nas lápides funerárias da classe burguesa. A dominação e a exploração burguesas passaram a ser concebidas como legítimas, na medida em que a riqueza não seria fruto do trabalho proletário, mas do trabalho burguês individual. Ao compor para o túmulo uma representação de um trabalhador, Del Debbio constitui uma representação de masculinidade que corresponde o ser homem e o ser trabalhador. Esta representação não emerge em uma realidade dada qualquer, mas é alimentada pelos lugares na história e na cultura paulistana: segundo Nicholson (2000, p. 39), é um ato político que reflete tanto o contexto no qual a imagem emerge quanto o futuro que se espera.

Um dos principais propagadores desta ideologia na primeira metade do século $X X$, em São Paulo, é o industrial Francesco Matarazzo (1854-1937), conhecido como Conde Matarazzo. Italiano de origem, imigrou para o Brasil em 1881. Inicialmente atuou como mascate, enriqueceu e veio a se tornar o criador do maior complexo industrial da América Latina no início do século $X X$. Este personagem fazia uso do discurso do enriquecimento por meio do próprio esforço, de acordo com as palavras de Martins:

Sempre que se dirigia aos trabalhadores, enfatizava os dados da sua biografia que podiam ser tomados como indicação de que havia sido um imigrante pobre e sem recursos que enriquecera no Brasil graças ao trabalho árduo e à aspiração de independência. Quando, porém, se dirigia à própria burguesia procurava enfatizar os componentes da sua biografia que destacavam a sua origem fidalga. Em decorrência, difundiuse entre os trabalhadores, durante mais de meio século, a concepção de que Matarazzo havia sido um imigrante muito pobre que, após trabalhar sofridamente nas fazendas de café, como colono, tornara-se vendedor ambulante, vivendo de pão e banana. Com isso conseguira guardar dinheiro, montar de início uma pequena fábrica de banha e, depois, outras industrias, para finalmente tornar-se milionário, dono de muitas empresas, patrão de milhares de operários (Martins, 1979, p. 149-150).

O trabalho é, portanto, tido como redentor, como possibilidade de libertação das mazelas sociais, quando há esforço suficiente para tanto. O complexo funerário erigido no Cemitério da Consolação, em homenagem ao filho do chamado Conde Matarazzo, é expressivo desta ideologização (FIGURA 13).

De autoria do escultor italiano Luigi Brizzolara (1868-1937), o Mausoléu da Família Matarazzo é uma das maiores edificações do gênero, ocupando uma área total de 150 metros quadrados. Construído em granito bege, a estrutura é adornada com um grande conjunto estatuário em bronze. A porção central tem cerca de vinte metros de altura e é coroada por uma cruz latina e uma Pietá. Outras figuras são de Santa Inês, São Francisco, Santa Filomena e São Constabilis, todas em bronze. A parte frontal é decorada ainda pelo brasão da família flanqueado por anjos, esculpido em mármore. 
FIGURA 13 - Mausoléu da Família Matarazzo (1925), em granito, mármore e bronze, de Luigi Brizzolara, Cemitério da Consolação.

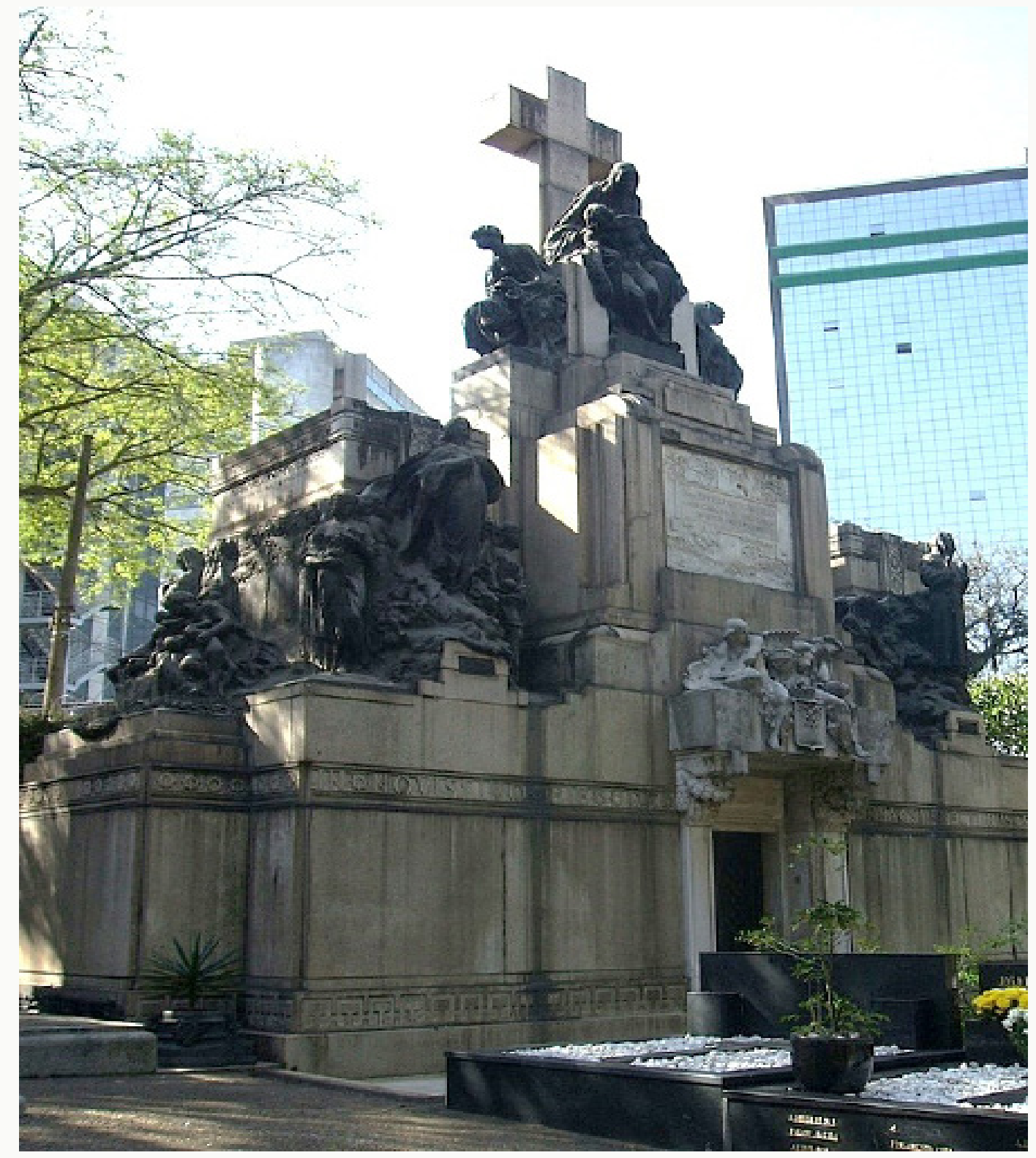

FONTE: acervo da autora, 2014.

Nas laterais encontram-se conjuntos escultóricos em homenagem à "família" e ao "labor" (FIGURA 14). No caso da representação do trabalho, observa-se a representação de uma figura masculina nua, sentada ao lado da mulher e de duas crianças. O trabalho aqui é indissociável da concepção de família. A atividade é vista como dignificadora do homem e condição possível de sua redenção. O sucesso individual do burguês é concebido enquanto fruto do empenho de suas próprias mãos. Conforme observa Piscitelli (2004, p. 192), o dinheiro burguês considerado "como dimensão masculina da riqueza" era o indicativo do sucesso: dissociado de qualquer conotação pejorativa, era um índice da moralidade e da dignidade alcançadas por meio do trabalho. Ou, 
seguindo as palavras de Butler (2013, p. 213), esta identificação ocorre porque as obras participam de uma "ontologia de gênero" que, operando no contexto político e social da modernidade paulistana, define certas exigências prescritivas - neste caso, como um homem deve ser.

FIGURA 14 - Detalhe do Mausoléu da Família Matarazzo.

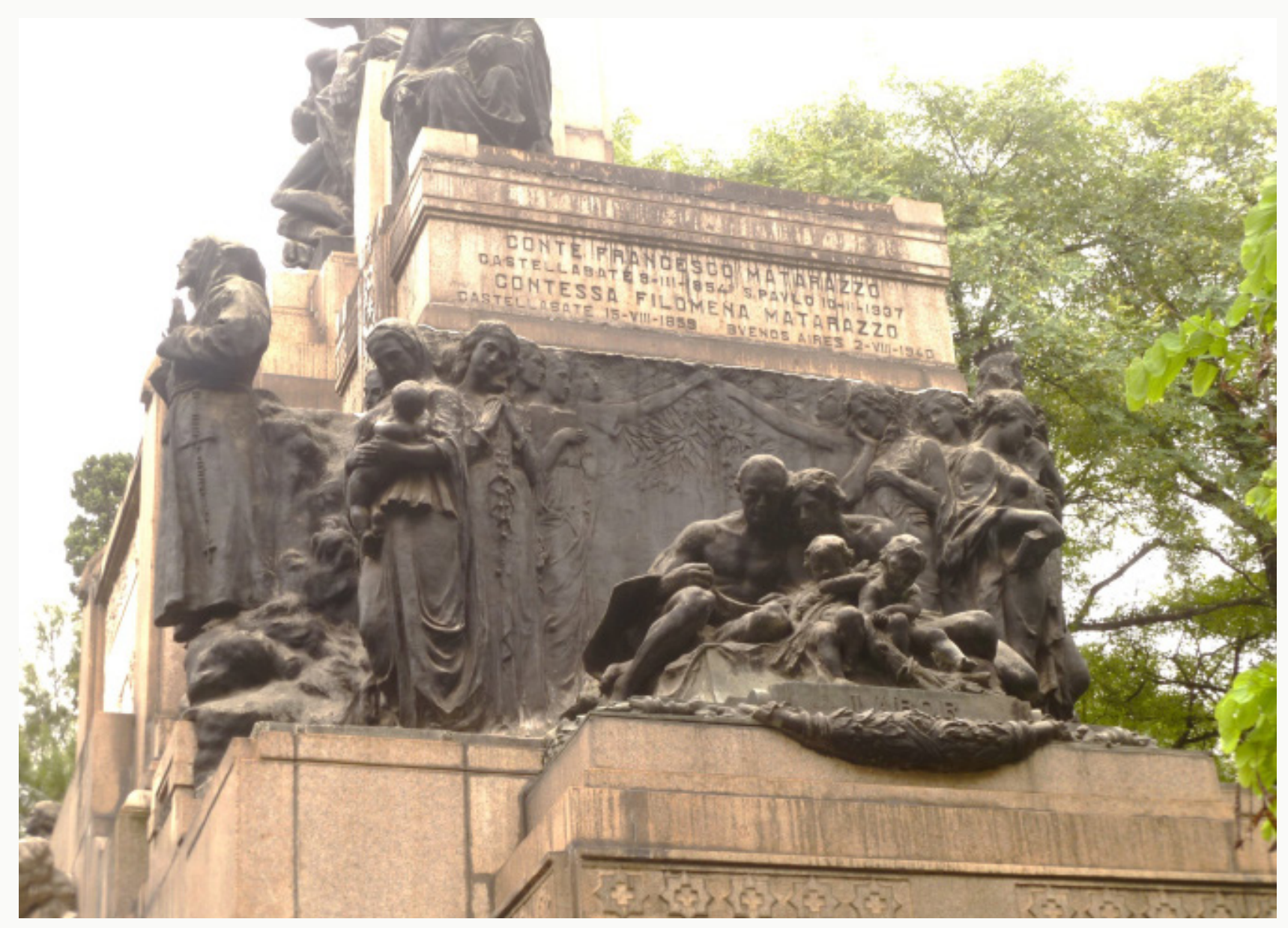

FONTE: acervo da autora, 2014.

Não obstante as convenções plásticas do tema postuladas por Brizzolara para esta sepultura tenderem ao realismo, e àquelas concebidas para as sepulturas de Rizkallah Jorge e da Família Calfat por Del Debbio serem mais modernas e hieráticas, o discurso ideológico inerente a ambos os escultores é similar: o trabalho é considerado o alicerce do caráter e do enobrecimento do imigrante/burguês. 


\section{Considerações Finais}

O trabalho assume em ambas as esculturas funerárias o papel arquétipo de representação da masculinidade enquanto força e virilidade a serviço da criatividade. A representação de cada homem seminu implica a valorização da masculinidade viril, do homem provedor, associado ao mundo do trabalho, em face da presença de instrumentos e/ou de atributos que remetem à atuação profissional. Observa-se que as representações de masculinidade associadas à virilidade, à força e ao vigor físico, como os exemplos apresentados, são as hegemônicas imagens do ideal de "ser-homem" no mundo burguês. Tal condição é em decorrência da valorização do trabalho e de sua função como engrandecimento social. Há que se ressaltar que a simbologia presente nos túmulos serve muitas vezes à individualização da sepultura e à construção da memória do falecido e/ou de sua família. A memória que estas famílias buscam perenizar está associada ao empreendedorismo das famílias em questão no espaço urbano paulistano. Afirma Nolasco:

O trabalho e o desempenho sexual funcionam como as principais referências para a construção do modelo de comportamento dos homens. Desde cedo, os meninos crescem assimilando a ideia de que, com o trabalho, serão reconhecidos como homens (Nolasco, 1993, p. 50).

Essa associação intrínseca entre homem e trabalho encontra sentido no contexto de industrialização crescente de São Paulo desde a virada do século XIX para o XX, conforme já observado. Ainda conforme $\mathrm{o}$ autor, efetivamente $\mathrm{o}$ trabalho define a primeira marca de masculinidade, porque no plano social viabiliza a saída da própria família, ao conferir ao homem certo status de independência. O homem torna-se um "indivíduo comprometido com uma obsessão "produtiva" e com a reprodução dos valores da ordem capitalista." (Nolasco, 1993, p. 51)

Segundo Berresford (2004, p. 128-130), representações de trabalho em associação com a figura do falecido começam a tornar-se mais comuns entre as décadas de 1850 e 1860 , pois assim como a mulher será identificada com a maternidade e a caridade, o homem será identificado com seu trabalho. Tais figuras podem ser expressas na imagem do sepultado em trajes contemporâneos, portando signos de seu ofício, como as balanças da justiça para um advogado, por exemplo. Monumentos mais elaborados podem incluir alegorias caracterizadas de acordo com o ramo de atuação do falecido. A aparição da figura do trabalhador humilde não é necessariamente um elogio às classes subalternas, mas ao burguês, industrial ou comerciante, que promove-se socialmente por intermédio do trabalho - o que ocorre nos túmulos em questão. O advento do Realismo Social na década de 1880, na Itália, não elimina certas convenções simbólicas e mitológicas da arte funerária, embora imprima maior dignidade à estatuária como um todo e incorpore elementos como o trabalhador, o avental de couro e as 
ferramentas, por vezes sobrepondo-os a elementos então mais convencionais, como o retrato do falecido e as figuras religiosas.

As estátuas de Del Debbio incorrem em uma relação triangular, estabelecida a partir de três pontos, quais sejam masculinidade, trabalho e virilidade, neste caso tomados como indissociáveis. Evidencia-se a virilidade como figurativa da própria força de caráter dos personagens, salientando - labor humano como fundamento da formação identitária do homem. Para além de sua identidade, destaca-se a formação do caráter do homem pela via do trabalho, construindo um modelo de masculinidade a ser seguido. "A masculinidade não é dada, é construída mediante um processo de diferenciação, no qual, longe de ser pensada como um absoluto, é relativa e reativa" (Matos, 2001, p. 95). As construções tumulares neste artigo expressam a masculinidade por meio das figurações dos trabalhadores. Edificam-se como forma de enobrecimento e perenizam a memória dos sepultados, enquanto homens de sucesso e honra.

O cemitério, lugar privilegiado para lidar com a questão da finitude, torna-se suporte para a exposição das representações de gênero. Por mais que a associação entre homem e labor pareça simplificada para as representações de masculinidade tecidas por Del Debbio, trata-se a rigor de uma imagem de poder, constituída em um panorama mais amplo e dinâmico de relações de dominação e exclusão. Na medida em que cada túmulo é pensado como espaço de síntese identitária, são reunidos fragmentos da trajetória dos sepultados e de suas famílias e/ou grupos sociais. Um dos fatores mais proeminentes destas identificações se dá a partir das construções e relações de gênero, culturais e relacionais, colaborando para a preservação dos lugares sociais destes indivíduos. Nesse sentido, as obras em questão constituem meios de distinção social e sedimentação social e cultural.

\section{Referências Bibliográficas}

ALBUQUERQUE JÚNIOR, Durval Muniz de. Nordestino: uma invenção do falo - uma história do gênero masculino. São Paulo: Intermeios, 2013. 254p.

ANDRESEN, Sophia de Mello Breyner. O nu na Antiguidade Clássica. Lisboa: Portugalia, 1992. 85p.

ARGAN, Giulio Carlo. Arte Moderna: do iluminismo aos movimentos contemporâneos. São Paulo: Companhia de Letras, 2008. 736p.

ARIĖS, Philippe. História da Morte no Ocidente. Da Idade Média aos nossos dias. Rio de Janeiro: Ediouro, 2003. 312p.

ARIĖS, Philippe. O homem diante da morte. São Paulo: Editora Unesp, 2014. 838p.

BARBOSA, Luciane Muniz Ribeiro. Igreja, Estado e educação em Martinho Lutero: uma análise das origens do direito à Educação. Dissertação (Mestrado em Educação). Faculdade de Educação, 
Universidade de São Paulo. São Paulo, 2007. 239p.

BATISTA, Stephanie Dahn. O corpo falante: narrativas e inscrições num corpo imaginário na pintura acadêmica do século XIX. Revista Científica/Fap. Curitiba, v. 5, p. 125-148, jan./jun. 2010. Disponível em <http://www.fap.pr.gov.br/arquivos/File/Revista_cientifica_5/revista5_Stephanie_Dahn_Batista. pdf>. Acesso: 06/09/2016.

BERRESFORD, Sandra. Italian Memorial Sculpture 1820-1940. A legacy of love. London: Frances Lincoln Limited, 2004. 256p.

BORDWELL, David \& THOMPSON, Kristin. Film Art: An Introduction, New York: Mc Graw-Hill, 2001. $458 \mathrm{p}$.

BORGES, Maria Elizia. A estatuária funerária no Brasil: representação iconográfica da morte burguesa. São Luís. In: VII Abanne - Gt Antropologia da Emoção. Edições do GREM, 8, 2004. Disponível em <http://www.artefunerariabrasil.com.br/admin/upload/artigos/texto\%20do\%20CD. pdf>. Acesso: 02/10/2016.

BORGES, Maria Elizia. Arte funerária no Brasil (1890-1930): Ofícios de Marmoraristas Italianos em Ribeirão Preto. Belo Horizonte: C/Arte, 2002. 312p.

BORGES, Maria Elizia. Arte Funerária no Brasil: contribuições para a historiografia da arte brasileira. In: Anais do XXII Colóquio Brasileiro de História da Arte. Rio Grande do Sul: PUCRS, 2003. Disponível em <http://www.artefunerariabrasil.com.br/admin/upload/artigos/coloquio\%20puc.pdf>. Acesso: 10/09/2016.

BUTLER, Judith. Problemas de gênero: feminismo e subversão da identidade. Rio de Janeiro: Civilização Brasileira, 2013. 237p.

CAMARGO, Luís Soares de. Viver e Morrer em São Paulo: a vida, as doenças e a morte na cidade do século XIX. 2007, 545 p. Tese (Doutorado em História Social), Programa de Pós-Graduação em História Social, Pontifícia Universidade Católica de São Paulo, São Paulo, 2007.

CHALHOUB, Sidney. Trabalho, lar e botequim: o cotidiano dos trabalhadores no Rio de Janeiro da belle époque. Campinas: Editora da Unicamp, 2008. 368p.

CHEVALIER, Jean e GHEERBRANT, Alain. Dicionário dos Símbolos. Rio de Janeiro: José Olympio, 2006. $996 p$.

CHIARELLI, Tadeu. A repetição diferente: aspectos da arte no Brasil entre os séculos XX e XIX. Crítica Cultural. Florianópolis, v. 4, n. 2, p. 125-161, dez. 2009. Disponível em <http://www. portaldeperiodicos.unisul.br/index.php/Critica_Cultural/article/view/139>. Acesso: 06/09/2016.

CHIARELLI, Tadeu. Pintura não é só beleza. A crítica de arte de Mário de Andrade. Florianópolis: Letras Contemporâneas, 2007. 325p.

CYMBALISTA, Renato. Cidades dos Vivos. Arquitetura e atitudes perante a morte nos cemitérios do estado de São Paulo. São Paulo: Annablume / Fapesp, 2002. 210p. 
DAWKINS, Richard. The ancestor's tale: a pilgrimage to the dawn of evolution. New York: Houghton Mifflin Company, 2005. 688p.

DIDI-HUBERMAN, Georges. O que vemos, o que nos olha. São Paulo: Editora 34, 1998. 264p.

DIDI-HUBERMAN, Georges. Ao passo ligeiro da serva (Saber das imagens, saber excêntrico). Projeto Ymago. Lisboa: KKYM, 2011a. Disponivel em <http://cargocollective.com/ymago/DidiHuberman-Txt-3>. Acesso em: 30/04/2016.

DIDI-HUBERMAN, Georges. Sobrevivência dos vaga-lumes. Belo Horizonte: Editora UFMG, $2011 \mathrm{~b}$. $164 p$.

DIDI-HUBERMAN, Georges. Quando as imagens tocam o real. Pós - Revista do Programa de PósGraduação em Artes da Escola de Belas Artes da UFMG. Belo Horizonte, v. 2, n. 4, p. 204-219, nov. 2012.

ELIAS, Norbert. A Solidão dos Moribundos, seguido de Envelhecer e morrer. Rio de Janeiro: Jorge Zahar, 2001. 108p.

FABRIS, Annateresa. Cândido Portinari. São Paulo: Edusp, 1996. 189p.

FAVARO, Cleci Eulália. Imagens femininas: contradições, ambivalências, violências. Porto Alegre: EDIPUCRS, 2002. 258p.

FRIAS, Paula Giovana Lopes Andrietta. A representação do universo caipira: fator de renovação na produção de Almeida Júnior. Revista Educare CEUNSP. São Paulo, v. 1, n. 1, p. 30-35, 2013.

GERAISSATI, Renata. Trajetória de um patrício: conhecendo Rizkallah Jorge Tahan e a construção de seu poder simbólico. Revista Outras Fronteiras. Cuiabá, v. 1, n. 2, p. 302-323, jul-dez. 2013. Disponível em <http://revistas.ufpr.br/clio/article/view/40407>. Acesso: 08/09/2016.

GOMBRICH, Ernst Hans. Os usos das imagens: estudos sobre a função social da arte e da comunicação social. Porto Alegre: Bookman, 2012. 304p.

GUTMANN, Matthew. Trafficking in men: the anthropology of Masculinity. Annual Review of Anthropology. Vol. 26 (1997), p. 385-409. Disponivel em: <https://www.jstor.org/ stable/2952528?seq=1\#page_scan_tab_contents>. Acesso em: 26/03/2017.

JOYCE, James. Ulysses. São Paulo: Penguin/Companhia das Letras, 2012. 1112p.

KATZ, Helena. Por uma teoria crítica do corpo. In: OLIVEIRA, Ana Cláudia de e CASTILHO, Kathia. (orgs.). Corpo e moda: por uma compreensão do contemporâneo. Barueri, SP: Estação das Letras, 2008, p. 69-74.

LE GOFF, Jacques. Para uma outra Idade Média: tempo, trabalho e cultura no ocidente. Petrópolis: Vozes, 2013. 534p.

MARQUEZAN, Reinoldo. Enfoque psicopedagógico na relação família e escola. Revista Educação 
Especial (UFSM). Santa Marai, v. 2, n. 28, p. 287-296, 2006. Disponível em <https://periodicos. ufsm.br/educacaoespecial/article/view/4304>. Acesso: 05/09/2016.

MARTINS, José de Souza. O Cativeiro da Terra. São Paulo: Editora Ciências Humanas, 1979. 157p.

MARTINS, José de Souza. $O$ que a morte não leva [entrevista a Miguel Glugoski]. Jornal da USP. Ano XXIV, no 847, 6 a 12 de outubro de 2008, p. 12-13. São Paulo: Coordenadoria de Comunicação Social - USP, 2008. Disponível em <http://www.usp.br/jorusp/arquivo/2008/jusp847/pag12.htm>.

Acesso: 30/05/2017.

MATIAS, Antônio Augusto Nogueira. O trabalho à luz da teologia de Santo Agostinho. Pensar: Revista Eletrônica da FAJE. Belo Horizonte, v. 5, n. 2, p. 257-266, 2014. Disponível em <http://faje. edu.br/periodicos/index.php/pensar/article/view/3010>. Acesso: 02/10/2016.

MATOS, Maria Izilda Santos de. Meu lar é o botequim: alcoolismo e masculinidade. São Paulo: Companhia Editora Nacional, 2001. 259p.

MATOS, Maria Izilda Santos de. Âncora de emoções: corpos, subjetividades e sensibilidades. Bauru: Edusc, 2005. 182p.

MATRANGOLO, Breno Henrique Selmine. Formas de bem morrer em São Paulo: transformações nos costumes fúnebres e a construção do cemitério da Consolação (1801-1858). 2013, 223p. Dissertação (Mestrado em História Econômica), Programa de Pós-Graduação em História Econômica da Faculdade de Filosofia, Letras e Ciências Humanas, Universidade de São Paulo, 2013.

MOTTA, Antonio. Estilos mortuários e modos de sociabilidade em cemitérios brasileiros oitocentistas. Horizontes Antropológicos. 2010, vol.16, n.33, p. 55-80.

NICHOLSON, Linda. Interpretando o gênero. Revista Estudos Feministas. Florianópolis, v. 8, n.2, p. 9-41, 2000. Disponível em <https://periodicos.ufsc.br/index.php/ref/article/view/11917>. Acesso: 12/09/2016.

NOLASCO, Sócrates. O mito da masculinidade. Rio de Janeiro: Rocco, 1993. 187p.

De Tarzan a Homer Simpson: banalização da violência masculina em sociedades contemporâneas ocidentais. Rio de Janeiro: Rocco, 2001. 318p.

PAGOTO, Amanda Aparecida. Do âmbito sagrado da igreja ao cemitério público: transformações fúnebres em São Paulo, 1850-1860. São Paulo: Imprensa Oficial, 2004. 160p.

PERUTTI, Daniela Carolina. Gestos feitos de tinta: as representações corporais na pintura de Almeida Júnior. Dissertação (Mestrado em Antropologia Social). Faculdade de Filosofia, Letras e Ciências Humanas. Universidade de São Paulo, São Paulo, 2007. 313p.

PESCl, Giovanna (orgs.). La Certosa di Bologna: Immortalita' della memoria. Bolonha: Editrice Compositori, 1998. 368p. 
PISCITELLI, Adriana. "Pioneiros": masculinidades em narrativas sobre fundadores de grupos empresariais brasileiros. In: SCHPUN, Mônica Raisa (org.). Masculinidades. São Paulo: Boitempo Editorial, 2004, p. 175-203.

REZENDE, Eduardo Coelho Morgado. O céu aberto na terra: uma leitura dos cemitérios de São Paulo na geografia urbana. São Paulo: E. C. M. Rezende, 2006. 184p.

RIBEIRO, Josefina Eloína. Escultores italianos e sua contribuição à arte tumular paulistana. Tese (Doutorado em História Social), Faculdade de Filosofia, Letras e Ciências Humanas, Universidade de São Paulo, São Paulo, 1999. 1262p.

RODRIGUES, Claudia. Nas fronteiras do Além: a secularização da morte no Rio de Janeiro (Séculos XVIII-XIX). Rio de Janeiro: Arquivo Nacional, 2005.

RUGGIERO, Antonio de. Os empreendedores toscanos do mármore nas cidades brasileiras (1875-1914). In: FAY, Claudia Musa e RUGGIERO, Antonio de. Imigrantes empreendedores na história do Brasil: estudos de casos. Porto Alegre: EDIPUCRS, 2014. 200p.

SANSON, Cesar. Trabalho e subjetividade: da sociedade industrial à sociedade pós-industrial. Tese (Doutorado em Sociologia). Setor de Ciências Humanas, Letras e Artes. Universidade Federal do Paraná, Curitiba, 2009. 156p.

SCOTT, Joan. Gênero: uma Categoria Útil de Análise Histórica. Educação e Realidade. Porto Alegre, v. 20, n. 2, p.71-99, 1995. Disponível em <https://repositorio.ufsc.br/bitstream/ handle/123456789/1210/scott_gender2.pdf>. Acesso: 10/09/2016.

SILVA, Joseli Maria et al. Espaço, gênero \& masculinidades plurais. Ponta Grossa: Todapalavra, 2011. 360p.

SORIO, Livia. Cemitérios da província: história e arte cemiterial em Porto Alegre. Porto Alegre: Edição do Autor, 2009. 148p.

SOUZA, Gilda de Mello e. Pintura brasileira contemporânea: os precursores. Discurso. São Paulo, Órgão Oficial do Departamento de Filosofia, FFLCH/USP, v. 5, p. 120-129, 1974.

TAYLOR, Charles. As fontes do self: a construção da identidade moderna. São Paulo: Loyola, 2005. 672p.

VALLADARES, Clarival do Prado. Arte e Sociedade nos Cemitérios Brasileiros. Rio de Janeiro: Conselho Federal de Cultura, 1972. 1487p.

VIEGAS, Alessandra Serra. A importância do corpo na sociedade grega: na vida e na morte. Nearco - Revista Eletrônica de Antiguidade. Rio de Janeiro, v. 1, n. 1, p. 13-26, 2008. Disponível em: <http://www.revistanearco.uerj.br/arquivos/numero1/arquivo2.pdf/>. Acesso em: 26/11/2015.

VIEIRA-SENA, Taísa. A construção da identidade masculina contemporânea por meio da roupa intima. Dissertação (Mestrado em Design), Programa de Pós-Graduação em Design, Universidade Anhembi Morumbi, São Paulo, 2011. 187p. 
VOVELLE, Michel. Imagens e Imaginário na História. Fantasmas e certezas nas mentalidades desde a Idade Média até o século XX. São Paulo: Ática, 1997. 407p.

WOLLECK, Aimoré. O trabalho, a ocupação e o emprego: uma perspectiva histórica. Revista Leonardo Pós. Indaial, v. 1, p. 1-15, 2002. Disponível em: <http://www.posuniasselvi.com.br/ artigos/rev01-05.pdf>. Acesso em: 19/10/2016.

Recebido em: 02 de janeiro de 2017

Aprovado em: 27 de abril de 2017 